\title{
Resident $T$ cells orchestrate adipose tissue remodeling in a site peripheral to infection
}

\author{
Authors: Agnieszka M. Kabat ${ }^{1,2}$, Alexandra Hackl ${ }^{1} \uparrow$, David E. Sanin ${ }^{1,2} \uparrow$, Patrice Zeis ${ }^{1,3,4} \uparrow$, \\ Katarzyna M. Grzes ${ }^{1,2}$, Francesc Baixauli ${ }^{1}$, Ryan Kyle ${ }^{1}$, George Caputa ${ }^{1}$, Joy Edwards- \\ Hicks ${ }^{1}$, Matteo Villa ${ }^{1}$, Nisha Rana ${ }^{1}$, Jonathan D. Curtis ${ }^{1,2}$, Angela Castoldi ${ }^{1}$, Jovana Cupovic ${ }^{1}$, \\ Leentje Dreesen ${ }^{5}$, Maria Sibilia ${ }^{6}$, J. Andrew Pospisilik ${ }^{7}$, Joseph F. Urban $\mathrm{Jr}^{8}$, Dominic \\ Grün ${ }^{1,9}$, Erika L. Pearce ${ }^{1,2,10}$, Edward J. Pearce ${ }^{1,2,4,11^{*}}$
}

\footnotetext{
Affiliations:

${ }^{1}$ Max Planck Institute for Immunobiology and Epigenetics, Freiburg 79108, Germany

${ }^{2}$ Bloomberg Kimmel Institute, and Department of Oncology, Johns Hopkins University School of Medicine, Baltimore, MD 21287, USA

${ }^{3}$ International Max Planck Research School for Molecular and Cellular Biology (IMPRS-MCB), Freiburg, Germany

${ }^{4}$ Faculty of Biology, University of Freiburg, Freiburg 79104, Germany

${ }^{5}$ Department of Pathology and Immunology, Washington University School of Medicine, St. Louis, MO 63110, USA

${ }^{6}$ Institute of Cancer Research, Medical University of Vienna, Comprehensive Cancer Center, Borschkegasse 8a, A-1090 Vienna, Austria

${ }^{7}$ Center for Epigenetics, Van Andel Research Institute, Grand Rapids, MI 49503, USA.

${ }^{8}$ USDA, Agricultural Research Service, Beltsville Human Nutrition Research Center, Diet, Genomics, and Immunology Laboratory, Beltsville, MD 20705, USA

${ }^{9}$ CIBSS-Centre for Integrative Biological Signaling Studies, University of Freiburg, Freiburg 79104, Germany

${ }^{10}$ Department of Biochemistry and Molecular Biology, Johns Hopkins University Bloomberg School of Public Health, Baltimore, MD 21287, USA

${ }^{11}$ Department of Molecular Microbiology and Immunology, Johns Hopkins University Bloomberg School of Public Health, Baltimore, MD 21287, USA
}

$\dagger$ These authors contributed equally to this work

*Corresponding author. Email: epearce7@jhmi.edu 
Abstract: Infection with helminth parasites can affect adiposity, but underlying mechanisms that regulate this process are unclear. We found that fat content of mesenteric adipose tissue (mAT) declined in mice during infection with gut-restricted parasitic worms. This was associated with the accumulation of metabolically activated, immunostimulatory cytokineand extracellular matrix-secreting multipotent stromal cells, which had potential to differentiate into preadipocytes. Concomitantly, mAT became infiltrated with Th2 lymphocytes that took up long-term residence and responded to signals from stromal cells by producing stromal cell-stimulating cytokines, including Amphiregulin. Signals delivered by Amphiregulin to stromal cells were required for immunity to infection. Our findings reveal intricate intercellular communication between Th2 cells and adipocyte progenitors and link immunity to intestinal infection to T cell-dependent effects on the adipocyte lineage.

Type 2 immune processes underlie aspects of tissue homeostasis. This is particularly well recognized in adipose tissue (AT), where eosinophils and type 2 innate lymphoid cells (ILC2) contribute to the maintenance of alternative macrophage activation, and are implicated in AT browning and the prevention of metabolic disease (1-4). Regulatory T (Treg) cells are also important for AT homeostasis $(5,6)$. Recently, stromal cells (SC) within visceral white AT were shown to produce IL-33, which sustains ILC2, eosinophil and Treg populations during homeostatic conditions (7-10). Infection with parasitic helminths drives type 2 immune responses, and $H$. polygyrus infection has been reported to prevent obesity in mice fed a high fat diet, through an IL-33-dependent pathway linked to AT browning (11, 12). Visceral AT was shown to undergo functional repurposing towards the production of antimicrobial molecules during inflammatory type 1 immune responses associated with disseminated infection with foodborne microbial pathogens (13). However, a detailed 
understanding of how AT changes during helminth infections is lacking. Recent work using single cell RNA sequencing allowed the identification of a lineage hierarchy of adipocyte progenitors, anchored in a population of MPC marked by Dpp4 expression (14). These MPC are depleted during insulin resistance and obesity, signaling their importance for maintaining AT homeostasis (14). We reasoned that immune responses to enteric parasites may affect lineage commitment within the mAT SC populations as a part of the tissue response to inflammation, and that this might account for changes in adiposity associated with helminth infection.

\section{Results}

\section{Dynamic changes occur in adipose tissue peripheral to the site of infection}

H. polygyrus infection is chronic, but can be cleared by anthelminthic treatment, after which mice show increased resistance to secondary challenge (Fig. S1). We found that infection-induced mesenteric lymph node $(\mathrm{mLN})$ enlargement was accompanied by a reduction in surrounding mAT (Fig. 1A), characterized by a decrease in mAT weight and fat content (Fig. 1B, C). This coincided with an increase in cellularity of the stromal vascular fraction (SVF), particularly after secondary infection, due to increases in immune and stromal cells in this compartment (Fig. 1D-F).

We noted that infection caused an increase in stromal cell size and side scatter, indicating that the cells had become activated and potentially secretory (Fig. 1G, H). To understand infection-associated changes in mAT, we performed RNAseq on sorted CD45$\mathrm{CD}^{-} 1^{-} \mathrm{Sca}^{+} \mathrm{PDGFR}^{+} \mathrm{SC}$. Pathway enrichment analysis revealed an emphasis on ECM and inflammation with expression of collagen, chemokine and cytokine genes during infection (Fig. 1I, J). Consistent with this, mAT SC isolated from infected mice constitutively secreted pro-collagen 1 (pCol1), TSLP and IL-33 when cultured ex vivo (Fig. 1K-M). 
The increased size, granularity and secretory activity of SC from infected mice suggested an increase in anabolic metabolism. This was confirmed by ex-vivo extracellular flux analysis, where mAT SC from infected mice had increased oxygen consumption rates (OCR) indicative of increased mitochondrial respiration (Fig. 1N, O) and increased extracellular acidification rates (ECAR) (Fig. 1P), indicative of increased production of lactate from glycolysis. OCR and ECAR paralleled the secretion of collagen and cytokines, being more pronounced after secondary infection (Fig. 10, P). Metabolic activation was important for altered stromal cell function since the selective glycolysis inhibitor heptelidic acid, which targets GAPDH, inhibited pColl production in parallel with reducing ECAR (Fig. 1Q, R).

\section{Th2 cells with innate immune cell properties take up long term residence in adipose tissue}

We explored infection-induced changes in the cellular composition of the SVF in greater detail using single cell (sc) RNAseq. Unsupervised clustering of SVF cell transcriptomes revealed multiple cell clusters (Fig. 2A, B, Fig. S2A). Striking infectioninduced changes within the immune cell compartment were apparent, with a reduction in myeloid cells and an expansion of the $\mathrm{CD}^{+} \mathrm{T}$ cell compartment (Fig. 2B-D). These changes were confirmed by flow cytometry (Fig. 2E, F), which also revealed an increase after infection of mAT eosinophils (Fig. 2G), that was not detected by scRNAseq. The majority of $\mathrm{mAT} \mathrm{CD}^{+} \mathrm{T}$ cells in infected mice were GATA3 ${ }^{+}$and therefore Th2 cells (Fig. 2H, S2). mAT Th2 cells were characterized by high expression of receptors for the stroma derived cytokines IL-33 and TSLP, whereas these cells constituted only a small percentage of mLN cells (Fig. 2H-J, Fig. S3A, B). Indeed, in secondary infection up to $80 \%$ of all $\mathrm{mAT} \mathrm{CD} 4^{+} \mathrm{T}$ cells were GATA3 ${ }^{+} \mathrm{IL}_{-33 \mathrm{R}^{+}}$Th2 cells (Fig. 2I). We found that mAT Th2 cells were CD69 ${ }^{+}$ $\mathrm{CD}_{4}{ }^{+}$and $\mathrm{CD}_{62} \mathrm{~L}^{-}$, suggesting that they were resident memory $\mathrm{T}$ cells $\left(\mathrm{T}_{\mathrm{RM}}\right)$ (Fig. S3C). Prior studies located AT resident T cells in tertiary lymphoid structures, also called fat 
associated lymphoid clusters (FALCs) $(13,15,16)$. In line with this, whole mount mAT confocal microscopy analysis revealed numerous FALCS enriched in $\mathrm{CD}^{+} \mathrm{GATA}^{+}(\mathrm{Th} 2)$ cells in the infected mice (Fig. S4A, B). These structures were rare and smaller in mAT from uninfected mice. Moreover, in infected mice Th2 cells were also present in areas outside of the FALCs, scattered among Perilipin- $1^{+}$adipocytes and PDGFRa ${ }^{+} \mathrm{SC}$ (Fig. S4B, C).

Prevention of Th2 cell development through the deletion of IL-4R $\alpha$ on T cells in $I l 4 r a^{\mathrm{fl} / f \mathrm{l}} \mathrm{Cd}$-Cre mice resulted in a reduction of resistance to secondary infection, and the loss of associated components of the response such as tissue eosinophilia (Fig. 2K-M), confirming the importance of Th2 cells for host defense during secondary infection. Functionally, the majority of mAT GATA $3^{+}$Th 2 cells were capable of making the eosinophil survival factor IL-5, but also the tissue modulatory cytokines Areg and TGF $\beta_{1}$ (Fig. 2N-R, Fig S5A, B); cells with these attributes were rare in the mLN from the same animals (Fig. S3C, D), consistent with the view that terminal Th2 cell differentiation occurs within peripheral tissues (17). scRNAseq data indicated that during infection Th2 $2_{\mathrm{RM}}$ cells became the main producers of Areg and TGF $\beta_{1}$ in the mAT, eclipsing the contribution of ILC2 (Fig. S5E). Lastly, we found that the increase in Th2 $2_{\mathrm{RM}}$ population was paralleled by the progressive infection-associated decline in mAT Treg cells and IFN- $\gamma$ producing $\mathrm{CD}^{+} \mathrm{T}$ cells (Fig. S5F, G), which was not apparent in infected $I l 4 r a^{\mathrm{fl} / \mathrm{fl}} C d 4$-Cre mice (Fig. S5H), indicating that Th2 cells compete with Treg and Th1 cells for the available mAT niche.

To ask whether mAT Th2 cells have tissue-specific attributes, we used scRNAseq to compare them to Th2 cells sorted from anatomically related sites affected by infection, namely the small intestine (SI) and mLN. Clustering and similarity analysis with VarID (18) revealed distinct groupings of T cell populations by tissue of residence (Fig. 3A,B). Cd44 ${ }^{+}$, $\mathrm{Cd} 9^{+}, \mathrm{Cd} 62 \mathrm{l}^{-}(\mathrm{Sell}), \mathrm{Klf2} 2^{-} \mathrm{Th} 2_{\mathrm{RM}}$ cells were present in mAT and SI but nevertheless clustered separately from each other (C7 vs. C11) (Fig. 3A, C), indicating location-dependent functional distinctions. Previous work has described Th2 $2_{\mathrm{RM}}$ cells in SI and the peritoneal 
cavity of $H$. polygyrus infected mice, but not in mAT (19). We observed that mAT, but not SI Th2 RM cells, upregulated the expression of CD25 (Il2 ra), and expressed high levels of Illrll (IL-33R, ST2), while SI Th2 ${ }_{\mathrm{RM}}$ cells displayed higher expression of $1117 r b$ (IL-25R), reminiscent of tissue-specific alarmin receptor expression in ILC2 (20) (Fig. 3D). Furthermore, Th2 $2_{\mathrm{RM}}$ cells from mAT, to a greater extent than SI Th2 $2_{\mathrm{RM}}$ cells, expressed several genes previously associated with ILC2: Nmur1, Calca (or Cgrp), Klrg1 and Arg1, indicating that $\mathrm{Th} 2_{\mathrm{RM}}$ cells acquire an "innate-like" phenotype when residing in mAT (Fig. 3D). In contrast to SI Th2 $2_{\mathrm{RM}}$ cells, mAT Th2 $2_{\mathrm{RM}}$ cells also expressed $C c r 2$, pointing towards a possible role for CCR2 ligands in Th2 ${ }_{\mathrm{RM}}$ cell localization in $\mathrm{mAT}$ (Fig. 3E). Moreover, analysis of integrin expression patterns by both scRNAseq and flow cytometry revealed that mAT Th2 $2_{\text {RM }}$ cells expressed integrins that enable them to interact with ECM (Fig. 3E, Fig S6A). Whereas the mAT Th2 $2_{\mathrm{RM}}$ cell cytokine signature was dominated by $I l 5, I l 6$, Areg and $T g f \beta_{1}$, SI cells additionally strongly expressed $I l 4$ and $I l 13$ (Fig. 3F).

Consistent with mAT Th2 cells being $\mathrm{T}_{\mathrm{RM}}$, Th2 cell accumulation during secondary infection was unaffected by treatment with FTY720, a sphingosine-1-phosphate receptor 1 agonist (Fig. 3G-J), indicating that the expansion of the mAT Th2 $2_{\mathrm{RM}}$ population is independent on the recruitment of cells from secondary lymphoid organs. Furthermore, FTY720 treatment had no effect on resistance to reinfection (Fig. 3K). It was striking that mAT remained enriched for IL-33R ${ }^{+}$Th2 ${ }_{\mathrm{RM}}$ cells capable of making both IL-5 and Areg for up to 11 months post treatment, while Treg and ILC2 populations within this tissue remained suppressed throughout this time (Fig. 3L-P). Indeed, the mAT Th2 RM population not only persisted, but continued to expand over time in the absence of infection (Fig. 3P). 


\section{Resident Th2 cells and stromal cells activate each other during infection}

When we examined mAT stromal cell activation in infected $I l 4 r a^{\mathrm{fl} / \mathrm{fl}} \mathrm{Cd} 4$-Cre mice, which lack Th2 cells, we found that cytokine and pColl production was diminished (Fig. 4A, B). There was also a failure of stromal cell activation when $\mathrm{CD}^{+} \mathrm{T}$ cells were depleted, an intervention that also resulted in the loss of resistance to infection (Fig. 4C-E, Fig. S7A-C). Th2 cells therefore play a critical role in mAT stromal cell activation during infection.

We asked whether SC reciprocally stimulate $\mathrm{Th} 2_{\mathrm{RM}}$ cells, by purifying and coculturing these populations and measuring Th2 cell survival and cytokine production. We found both to be significantly enhanced in the presence of mAT SC from infected and naive mice (Fig. 4F-H). These effects were seen when mAT Th2 $2_{\mathrm{RM}}$ cells and mAT SC were cultured in a trans-well system, or when Th2 RM cells were cultured with stromal cell conditioned medium, indicating that soluble factor(s) from SC drive $\mathrm{Th} 2_{\mathrm{RM}}$ cell activation (Fig. S7D).

The expression of TSLPR and IL-33R on mAT Th2 cells, and the recognized relationship of TSLP and IL-33 with type 2 immunity, suggested that it could be these cytokines that are responsible for the observed effects. To examine this possibility, we sorted both Th2 cells $\left(\mathrm{CD}^{+}{ }^{+}\right.$Foxp3-IL-4 $\left.{ }^{+}\right)$and non-Th2 T cells (CD4 ${ }^{+}$Foxp3-IL-4-) from mAT and mLN of infected animals and cultured them in the presence or absence of IL-33 and TSLP. We found that mAT Th2 $2_{\text {RM }}$ cells were intrinsically more capable of surviving in vitro than non-Th2 cells or mLN Th2 cells, and that they proliferated extensively in the absence of added growth factor (Fig. 4I, Fig. S7E). This distinction was further enhanced by the addition of IL-33 or TSLP (Fig. 4I, Fig. S7E). Furthermore, these cytokines activated mAT Th2 cells to produce Areg, IL-5, IL-6, IL-13 and TGF $\beta_{1}$ in an antigen independent manner (Fig. 4J, Fig. S7F).

While IL-33-induced cytokine production more strongly than TSLP, TSLP had a comparable effect on mAT Th2 $2_{\mathrm{RM}}$ survival, suggesting that TSLP might be more important in 
the long-term maintenance of these cells. The TSLP receptor is a heterodimer of the Crlf2 and IL-7R $\alpha$, the latter of which, when paired with $\gamma_{\mathrm{c}}$ (encode by Il2rg) is also a component of the bona fide IL-7R. Both TSLP and IL-7 receptors signal through STAT5 to promote T cell and ILC homeostasis (21). Th2 $2_{\mathrm{RM}}$ cells express Crlf2, Il7 ra and Il2rg suggesting that they may use TSLP or IL-7 to establish their dominance in the mAT lymphoid niche (Fig. 2J, Fig. S8A-C). Antibody-mediated blockade of IL 7R $\alpha$ for one week during post-infection recovery resulted in significant decreases in Th2 cells, and in $\mathrm{Ki} 67^{+} \mathrm{Th} 2$ cells in $\mathrm{mAT}$, but not in $\mathrm{mLN}$, confirming a requirement for TSLP/IL-7 signaling for Th2 $2_{\mathrm{RM}}$ cell proliferation and persistence (Fig. 4K-N). The decline in mAT Th2 $2_{\mathrm{RM}}$ cells caused by IL-7R $\alpha$ blockade also resulted in a decrease in mAT eosinophilia (Fig. S8D-F). Since we could not detect IL-7 in SC culture supernatants (not shown) and $I l 7$ was not strongly expressed in scRNAseq data (Fig. S8G), these results likely reflect the inhibition of TSLP-mediated effects. Together, our data point to the existence of a positive feedback loop in which Th2 ${ }_{\mathrm{RM}}$ cells in the mAT activate SC to secrete IL-33 and TSLP, which in turn promote $\mathrm{mAT}$ Th2 $\mathrm{RM}_{\mathrm{RM}}$ cell expansion, survival and cytokine production.

\section{Activated stromal multipotent progenitor cells accumulate and secrete collagen and immunostimulatory cytokines}

To more fully explore the mAT stromal response to infection we re-clustered the scRNAseq stromal cell transcriptomes and identified 6 distinct cell groups (C0-C5, Fig. 5A, Fig. S9A, B). Using recently published transcription profiles to delineate adipocyte differentiation stages, we identified $\mathrm{Dpp}^{+} \mathrm{Pi}^{+} 6^{+} \mathrm{MPC}$ (C2), intermediate uncommitted cells (C0), as well as Fabp4 ${ }^{+}$Parg $^{+}$committed preadipocytes (C1) $(14,22,23)$. Other clusters were enriched in $C D 9^{+}$matrix fibroblasts (C3) (24) and Ccl19+ immunofibroblasts (C4) (25) (Fig. 5A, Fig. S9A, B). By pseudotemporal ordering using Monocle (26) with MPC (C2) set 
as the origin, our data conformed with the preadipocyte to adipocyte differentiation model proposed by others (14) (Fig. 5B). A quantitative assessment of cluster sizes revealed an $\sim 25 \%$ increase in MPC (C2) and a decrease in intermediate uncommitted cells $(\mathrm{C} 0)$, in infected versus control mice (Fig. 5C), suggesting a block in the differentiation of the MPC towards the adipocyte lineage.

We used flow cytometry to address this further, gating on $\mathrm{CD} 45^{-} \mathrm{CD} 31^{-} \mathrm{Sca} 1^{+}$ PDGFR $\alpha^{+}$SC and using antibodies against surface molecules identified previously $(14,23)$ and in our data as marks of particular clusters, to quantitate MPC, which more strongly express $L y 6 c$ and Thyl (C2), versus fibroblast clusters, which more strongly express $C d 9$, or CD $9{ }^{\text {lo }}$ Ly $6 \mathrm{c}^{\text {lo }}$ committed preadipocytes (C1) (Fig. 5D). Infection led to increased frequencies of MPC and reduced frequencies of committed preadipocytes (Fig. 5E-G). To verify functional differences between identified stromal subpopulations we sorted them based on Ly6c and CD9 expression (Fig. 5E) and asked which had the potential to become adipocytes under adipogenic culture conditions (14). We found that the committed preadipocytes had the highest adipogenic potential, evident by extensive lipid droplet development, while MPC showed intermediate adipogenic potential. The matrix fibroblast subpopulation contained few cells that were able to differentiate into mature adipocytes (Fig. 5H, Fig. S9C). Infection did not affect the inherent ability of cells within the different stromal subpopulations to differentiate into mature adipocytes in culture (Fig. 5H, Fig. S9C). These data confirmed the functional relatedness of the clusters identified in our study to previous descriptions of adipocyte differentiation $(14,23,24)$.

We asked whether infection induced stroma cell remodeling could be attributed to a particular subpopulation of mAT SC. We found that pColl was produced by sorted matrix fibroblasts and MPC, and that both of these populations produced more pColl when sorted from infected mice (Fig. 5I). However, the MPC made more pColl than did the matrix fibroblasts, despite indications from the scRNAseq data that the opposite would be the case 
(discussed below). By comparison, committed preadipocytes from infected mice made little pCol1 (Fig. 5I). Additionally, MPC were the major source of TSLP, production of which was greatly increased as a result of infection $(\mathbf{F i g} . \mathbf{5 J})$.

Of relevance, given the expression of the IL-33R by mAT Th2 $2_{\mathrm{RM}}$ cells, and the effects of this cytokine on these cells, MPC expressed Il33 more strongly than any of the other stromal populations, in line with previous reports $(7,8)$ (Fig. S9D). They also expressed the chemokine encoding genes $C c l 2$, the ligand for CCR2, which is expressed on Th2 $2_{\mathrm{RM}}$ cells, and Ccl11, which encodes an eosinophil attractant (Fig. S9D), as well as genes encoding ECM components and modifying enzymes, including Fn, Postn, Ugdh, Pcolce2, and $p$ Colla2 (Fig. S9E, F), although expression of the latter, as well as $p$ Colla2, $p$ Colla1, pCol3al and $p$ Col6aland Eln was strongest in matrix fibroblasts in the stroma (Fig. S9F).

Together, our findings support the view that there is an infection-associated shift in the mAT stromal cell population structure such that MPC accumulate in the tissue and that this is coincident with a reduction in organ size and fat storage. The MPC express genes which indicate that they are able to respond to, recruit and stimulate $\mathrm{Th} 2_{\mathrm{RM}}$ cells, and attract eosinophils, while at the same time modulating the tissue ECM.

\section{Activated stromal cells are critical for host protective immunity to infection}

Our data indicated that $\mathrm{mAT}$ Th2 $2_{\mathrm{RM}}$ cells are able to interact with $\mathrm{SC}$, in a manner that allows reciprocal functional regulation in the context of an intestinal infection. We used Cell Phone (27) to specifically interrogate potential interactions between $\mathrm{Th} 2_{\mathrm{RM}}$ cells and MPC, the stromal cell population which showed the most dynamic changes during infection. The results of this analysis emphasized interactions involving the products of $T s l p r$ and $T s l p$, as well as the chemokine receptor $C c r 2$ with $C c l 2$ and $C c l 11$ and interactions involving integrin complexes expressed by $\mathrm{mAT}$ Th2 $2_{\mathrm{RM}}$. It also highlighted interactions between 
Th2 $2_{\mathrm{RM}}$-derived TGF $\beta_{1}$ and its receptors and the possibility of Areg-EGFR crosstalk (Fig. 6A).

We were intrigued by the role of Areg, since relatively little is known about its effects on AT biology. We began by broadly examining the effects of Areg on mAT SC in an ex vivo culture system. We found that mAT SC cultured in the presence of Areg had higher basal OCR and spare respiratory capacity (SRC) (28), indicating marked effects on metabolism (Fig. 6B-D). While the presence of Areg did not affect the secretion of IL-33 by mAT SC, it promoted the production of pCol1 and TSLP (Fig. 6E-G). Thus, Areg stimulated mAT SC from naïve mice shared metabolic and functional characteristics with activated mAT SC from infected mice. We then examined the effects of Areg on mAT by directly injecting naïve mice with this cytokine. We found increased numbers of immune and SC (Fig. S10A-C), which is consistent with the observed effects of infection. We then generated mice which lack EGFR on SC using Pdgfra-Cre (Egfr $r^{\mathrm{fl} / \mathrm{fl}}-P d g f r a-C r e$ mice); Pdgfra is broadly expressed in SC and anti-PDGFR $\alpha$ was used here to sort SC from mAT. Consistent with a role for Areg in modulating mAT SVF cellularity, we found fewer SC and immune cells in the mAT of

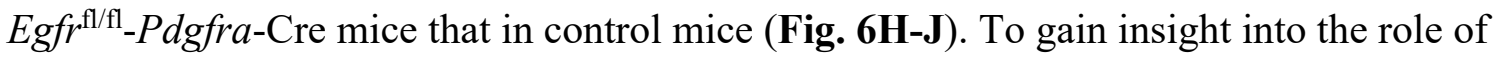
EGFR in mAT SC biology during infection, we performed RNAseq of mAT SC isolated from infected Egfrfl/fl-Pdgfra-Cre and control mice. Lack of EGFR resulted in reduced expression of several genes characteristic of AT MPC, including Dpp4, Anxa3 and Cd55 (14, 29) (Fig. 6K), suggesting that Areg signaling through EGFR plays a role in maintaining the identity of the progenitor population during infection. We also found that $\mathrm{mAT}$ SC from infected $E g f r^{\mathrm{fl} / \mathrm{fl}}-P d g f r a-C r e$ mice produced less TSLP ex vivo than did SC from infected controls (Fig. 6L). Lastly, Egfr $r^{\mathrm{fl} / \mathrm{fl}}$-Pdgfra-Cre mice were more susceptible to H. polygyrus infection compared to control mice (Fig. 6M, N). Together, these data indicate that EGFR expression on SC regulates adipocyte lineage differentiation and immunity to $H$. polygyrus. 


\section{Discussion}

Here we show that the mAT response to an enteric parasitic infection is marked by coordinated, interactional changes in the immune and stromal compartments. Most strikingly, a population of $\mathrm{Th} 2_{\mathrm{RM}}$ cells expands to dominate the mAT lymphocyte niche, and in response to signals from SC, provides activating cytokines that drive the functional reprograming of the stroma. These effects encompass major changes in anabolic metabolism, gene expression and developmental trajectories that result in MPC becoming ECM-, cytokine- and chemokine-producing cells. The fact that these changes are exaggerated after exposure to secondary infection indicates that the tissue retains memory of the primary event. Understanding how Th2 $2_{\mathrm{RM}}$ cells regulate tissue biology through effects on tissue SC holds promise for the development of targeted tissue-regenerative therapeutics.

Pathways of adipocyte SC differentiation were defined in detail recently, but how these are modulated by physiological perturbations has so far been studied mostly in the context of obesity $(8,14,23)$. We found that the Th2 response associated with $H$. polygyrus infection had a significant impact on the composition of mAT SC populations, characterized by a shift towards $\mathrm{Dpp} 4^{+} \mathrm{Pil6^{+ }} \mathrm{MPC}$, which became the primary producers of cytokines and collagen within the stroma. Our results are reminiscent of the situation in chronic rhinosinusitis, where type 2 inflammation causes a shift into a non-committed state in epithelial cells at sites of polyp formation (30). Dpp $4^{+} P i 16^{+}$stromal progenitors were recently identified across different tissues in mice and humans, as a universal reservoir population containing cells capable of giving rise to differentiated fibroblast subsets (29). Further work is required to fully understand the population structure of progenitor cells in the context of infection, but it is of interest that apparent plasticity between adipocyte and fibroblast lineages during tissue damage has been noted $(31,32)$. Taken together the findings suggest the possibility that expansion and activation of the universal reservoir SC population 
might be a hallmark of the physiological response to type 2 inflammation that is shared across tissues. We speculate that the benefit of such a response is linked to the plasticity of $\mathrm{SC}$ in the universal reservoir population to assume new supportive functions in response to signals received from the immune system. In the case of infection with $H$. polygyrus, we believe that the accumulation of the MPC population effectively stalls differentiation into committed preadipocytes, a process that would be expected to result in the reduction in AT mass associated with infection, and which may explain previous reports that $H$. polygyrus infection can prevent obesity (11).

mAT activation in infected mice shares some features, including the activation of SC to make Col1A1, with the creeping fibrotic mAT of Crohns disease, that serves to prevent the systemic spread of intestinal bacteria which translocate across the gut wall due to loss of epithelial integrity associated with the disease (33). H. polygyrus are not thought to penetrate the serosal surface, but based on the creeping mAT model, we speculate that increased collagen deposition within the mAT may reflect a defensive process aimed at increasing the strength and resilience of the intestine and its associated vasculature to minimize the possibility and consequences of perforation. Despite the presence within the mAT of $C D 9^{+}$ matrix fibroblasts, which strongly expressed collagen genes, the MPC were the main source of pCol1 protein during infection. The mechanical stiffness of the ECM is capable of influencing stem cell fate determination (34), so it is feasible that changes in ECM observed here could contribute to the accumulation of MPC during infection. Perhaps related to this, MPC differentiation can also be restrained by TGF $\beta_{1}(14)$, and in this context it is notable that $\mathrm{mAT}$ Th2 $2_{\mathrm{RM}}$ cells produced this cytokine. Both $\mathrm{TGF} \beta_{1}$ and the Th2 cell cytokine IL-13 are strongly implicated in fibrotic disease (35), although infection-associated changes in ECM in mAT did not develop into persistent fibrotic remodeling during infection (data not shown), indicating that inflammatory and healing responses in mAT are well controlled in this setting. 
Persistence of a large population of $\mathrm{mAT}$ Th2 $2_{\mathrm{RM}}$ cells almost a year post-clearance of infection was striking and consistent with reports of the longevity of lung Th2 $2_{\mathrm{RM}}$ cells (36). Th2 RM cells within mAT expressed Arg1, Nmurl and Calca, which have previously been considered to be primarily expressed by ILC2 (37-40). This pattern of gene expression, together with their ability to become activated in an antigen-independent manner, supports the view that innate reprograming of Th2 cells is an integral part of terminal differentiation driven by exposure to tissue-derived cytokine such as TSLP and IL-33 $(17,41,42)$. We speculate that immunologic remodeling of mAT with adaptive immune cells that have acquired the ability to become activated in response to innate signals may influence the susceptibility of this tissue to other insults, such as the establishment of cancer metastases, or infection by pathogens that require Th1 or Th17 responses for resolution.

In addition to classic type 2 cytokines, $\mathrm{mAT}$ Th2 $2_{\mathrm{RM}}$ cells also produced the growth factor Areg. The fact that Areg can release TGF $\beta_{1}$ from latent $\mathrm{TGF} \beta_{1}$ through integrin- $\alpha_{\mathrm{v}}$ activation (43) indicates that polyfunctional $\mathrm{Th} 2_{\mathrm{RM}}$ cells capable of making both cytokines may be particularly potent sources of active TGF $\beta_{1}$. Relatively little is known of roles for Areg and EGFR signaling in AT physiology. We observed that Areg can drive TSLP production by mAT SC. This crosstalk between Areg and TSLP production could stabilize the lymphoid niche within the tissue and therefore have implications for the persistence of Th2 $2_{\text {RM }}$ cells in mAT. Deletion of Egfr also emphasized the importance of Areg signaling for modulating SVF cellularity in mAT, and for protective immunity against an enteric infection. While our experiments did not allow identification of mAT SC as those critical for immunity, they nevertheless support an emerging view of immune cell driven EGFR signaling in SC providing a critical component of tissue immunity against infection.

Our findings on mAT fit with the growing realization that AT can provide help to tissues fighting infection or recovering from wounding $(13,44-46)$. These findings warrant broader consideration of the function of AT during disease. The extent to which changes in 
bioRxiv preprint doi: https://doi.org/10.1101/2022.02.24.481701; this version posted February $26,2022$. The copyright holder for this

preprint (which was not certified by peer review) is the author/funder, who has granted bioRxiv a license to display the preprint in perpetuity. It is made available under aCC-BY-NC-ND 4.0 International license.

populations of resident immune cells affect the helper activity of AT has been unclear, but our findings indicate that this may be of major significance since immune cells and AT SC have evolved powerful dynamic mechanisms for reciprocal activation and regulation. 
Acknowledgments: The authors thank Drs. Mark Wilson, Asifa Akhtar, Maximilian Seidl, Rick Maizels, Peter Murray, Sabine Eming, Axel Roers and David Vöhringer for reagents and helpful discussions, the core facilities at the MPI-IE and at the Institute of Clinical Pathology, University of Freiburg, for their support, and Andrea Quintana, John Sutherland and Fabian Haessler for help with animal colonies.

\section{Funding:}

National Institutes of Health grant AI 110481 (EJP)

German Research Foundation grant DFG FOR 2599 (EJP, AMK)

German Research Foundation grant under Germany's Excellence Strategy CIBSS

EXC-2189 Project ID 390939984 (DG)

German Research Foundation grant SPP1937 GR4980/1-1 (DG)

Alexander von Humboldt Fellowship Foundation (AMK, MV, FB, JC)

CAPES/Alexander von Humboldt Fellowship Foundation grant 88881.136065/2017-

01) (AC) Marie Skłodowska-Curie action Individual fellowship MSCA-IF (FB, JC)

European Research Council Advanced grant ERC-2015-AdG TNT-Tumors 694883

(MS)

European Union's Horizon 2020 research and innovation program under the Marie

Skłodowska-Curie grant agreement No. 766214 Meta-Can (MS)

Max Planck Society

\section{Author contributions:}

Conceptualization: AMK, DES, JAP, ELP, EJP

Methodology: DES, PZ, NR, JEH, DG

Investigation: AMK, AH, KMG, PZ, LD, RK, GC, JDC, AC, MV, FB, JC 
Visualization: AMK, FB, DES, PZ

Funding acquisition: ELP, EJP

Supervision: EJP

Resources: JFU, MS

Writing: AMK, EJP

Competing interests: EJP and ELP are founders of Rheos Medicines. ELP is a SAB member of ImmunoMet Therapeutics. 
A

\section{Control}

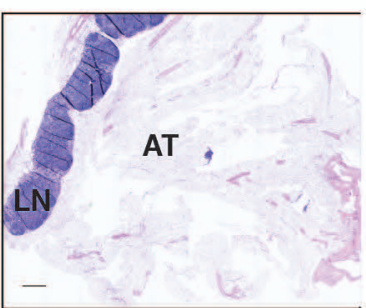
Primary H.poly

C

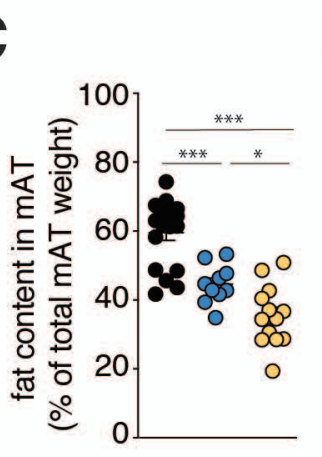
perpetuity. It is made available under aCC-BY-NC-ND 4.0 Inte $\mathbf{3}$ tional license.

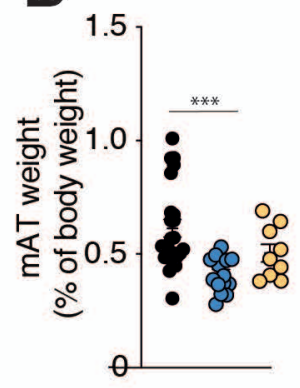

- Control

O Primary infection o Secondary infection \begin{tabular}{llllllll} 
& \multicolumn{8}{c}{$\log _{10} p$ value } \\
0 & 2 & 4 & 6 & 8 & 10 & K
\end{tabular} \begin{tabular}{l}
\hline extracellular structure organization \\
extracellular matrix organization \\
G protein-coupled receptor signaling pathway \\
inflammatory response \\
humoral immune response
\end{tabular}

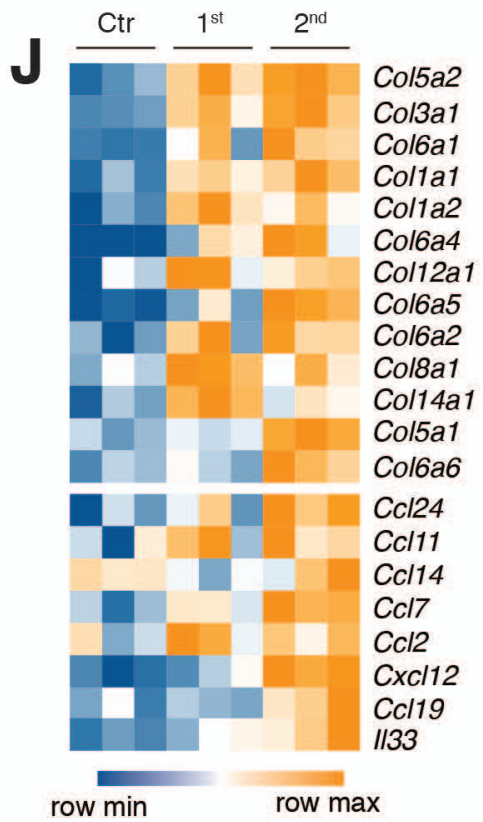

0
E

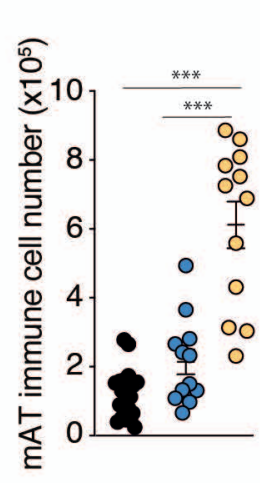

F

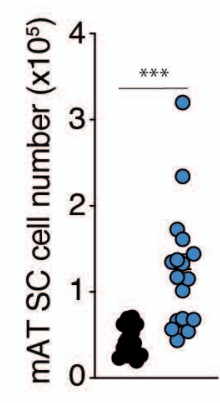

G

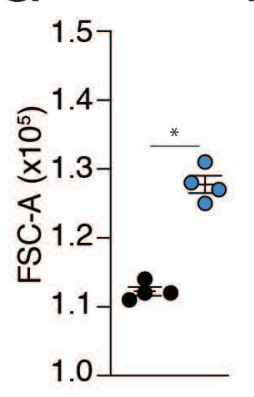

H

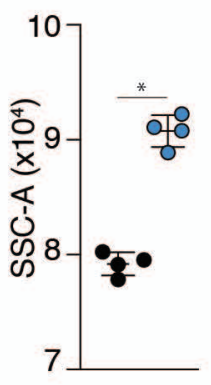

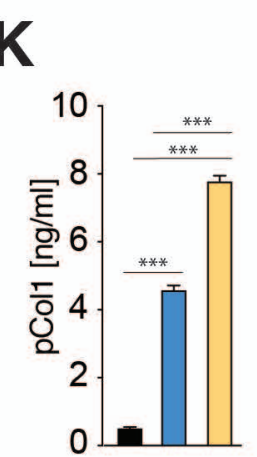
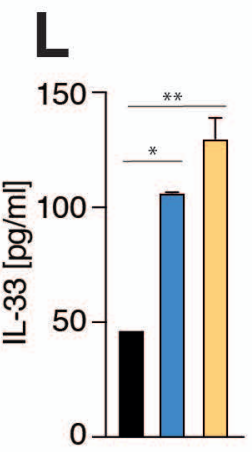

M

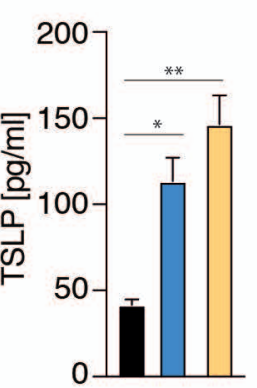

N
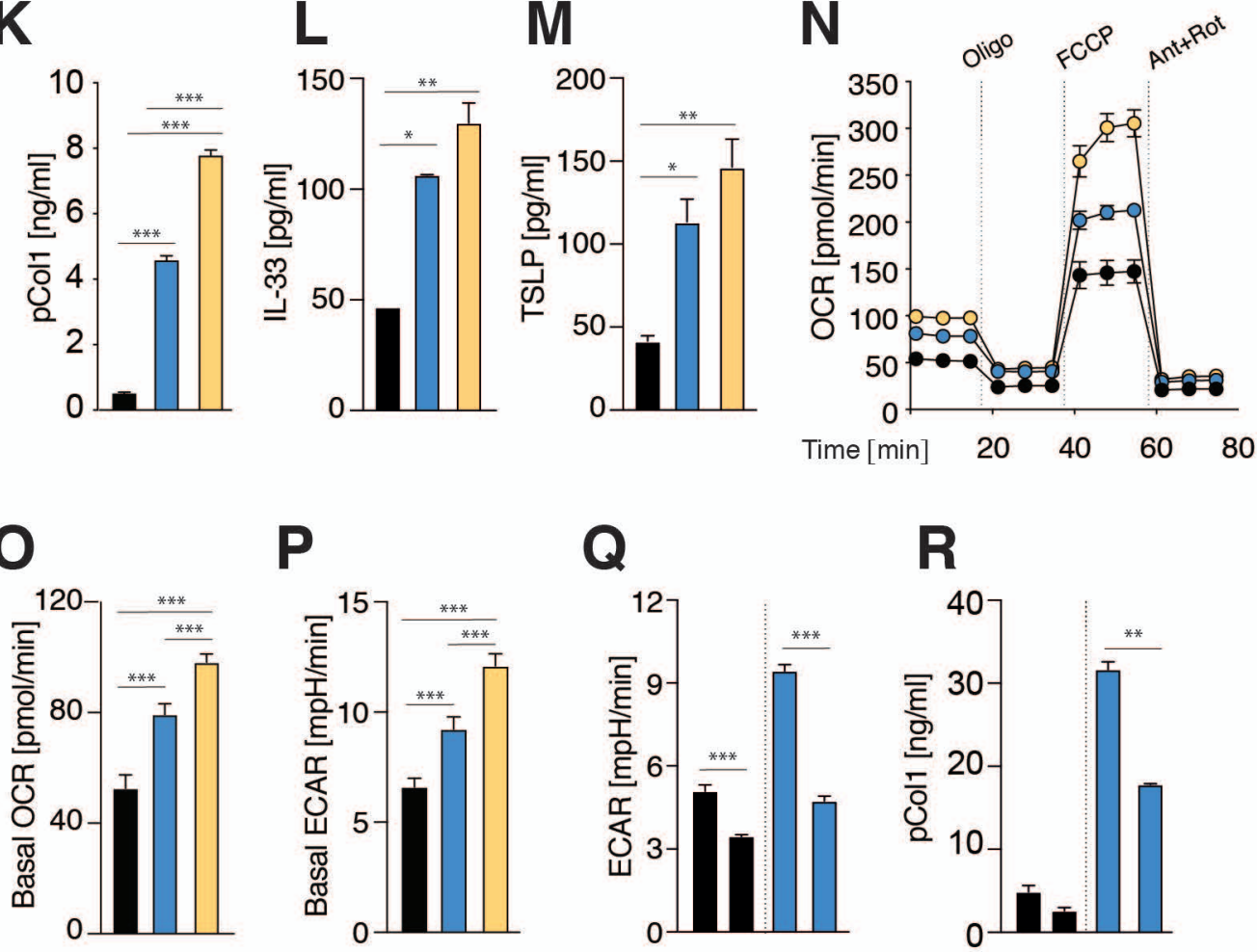

- Control

- Primary infection

O Secondary infection
P

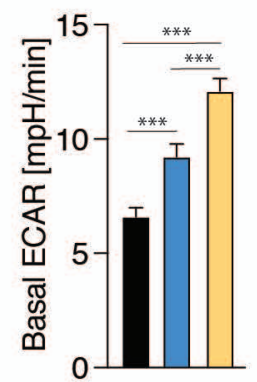

Q

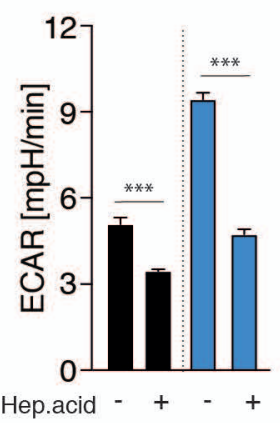

R

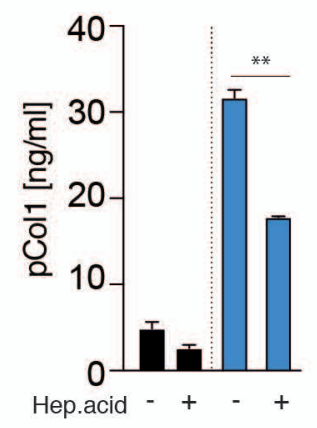




\section{Fig 1. mAT SC ECM production and metabolic rates are upregulated during $\boldsymbol{H}$.}

\section{polygyrus infection.}

(A). H\&E staining of mAT and mLN during H. polygyrus infection, scale bar $500 \mu \mathrm{m}$ (LNlymph nodes, AT - adipose tissue). (B) Weight of mAT of normalized to total body weight.

(C) Fat content in mAT measured by MRI and normalized to the total mAT weight. (D-F).

Total SVF cell counts (D), immune cell counts (gated on live $\mathrm{CD} 45^{+} \mathrm{CD} 31^{-}$cells) (E) and SC counts (gated on live CD45- CD31- PDGFR $^{+} \mathrm{Sca}^{+}$) (F) (G, H) Cell size (G) and granularity (H) of SC from mAT of control and infected mice. (I) GO enrichment analysis of significantly upregulated genes in SC from control vs primary infections. (J) Heatmap showing collagen, cytokine and chemokine expression pattern in SC isolated from mAT of control, and infected mice. (K-M) Pro-collagen 1 (pCol1) (K), IL-33 (L) and TSLP (M) production by mAT SC of control and infected mice. (N) Oxygen consumption rates, OCR, of mAT SC from indicated conditions at baseline and after Oligomycin (Oligo), FCCP and Rotenone/Antimycin (Rot/Ant) injections. (O) Baseline OCR in mAT SC. (P) Baseline extracellular acidification rates, ECAR, of mAT SC. (Q, R) Effects of heptelidic acid $[10 \mu \mathrm{M}]$ on baseline ECAR (Q) and pCol1 production (R) of mAT SC of control and infected mice.

Dots represent biological replicates (BR), error bars represent SEM from BR (B-H) or technical replicates (TR) (K-R). Data combined from 2-3 independent experiments (B-F), representative of 2-3 experiments (A, G, H, K-R), or from one experiment (I, J). 
bioRxiv preprint doi: https://doi.org/10.1101/2022.02.24.481701; this version posted February 26, 2022. The copyright holder for this

preprint (which was not certified by peer review) is the author/funder, who has granted bioRxiv a license to display the preprint in
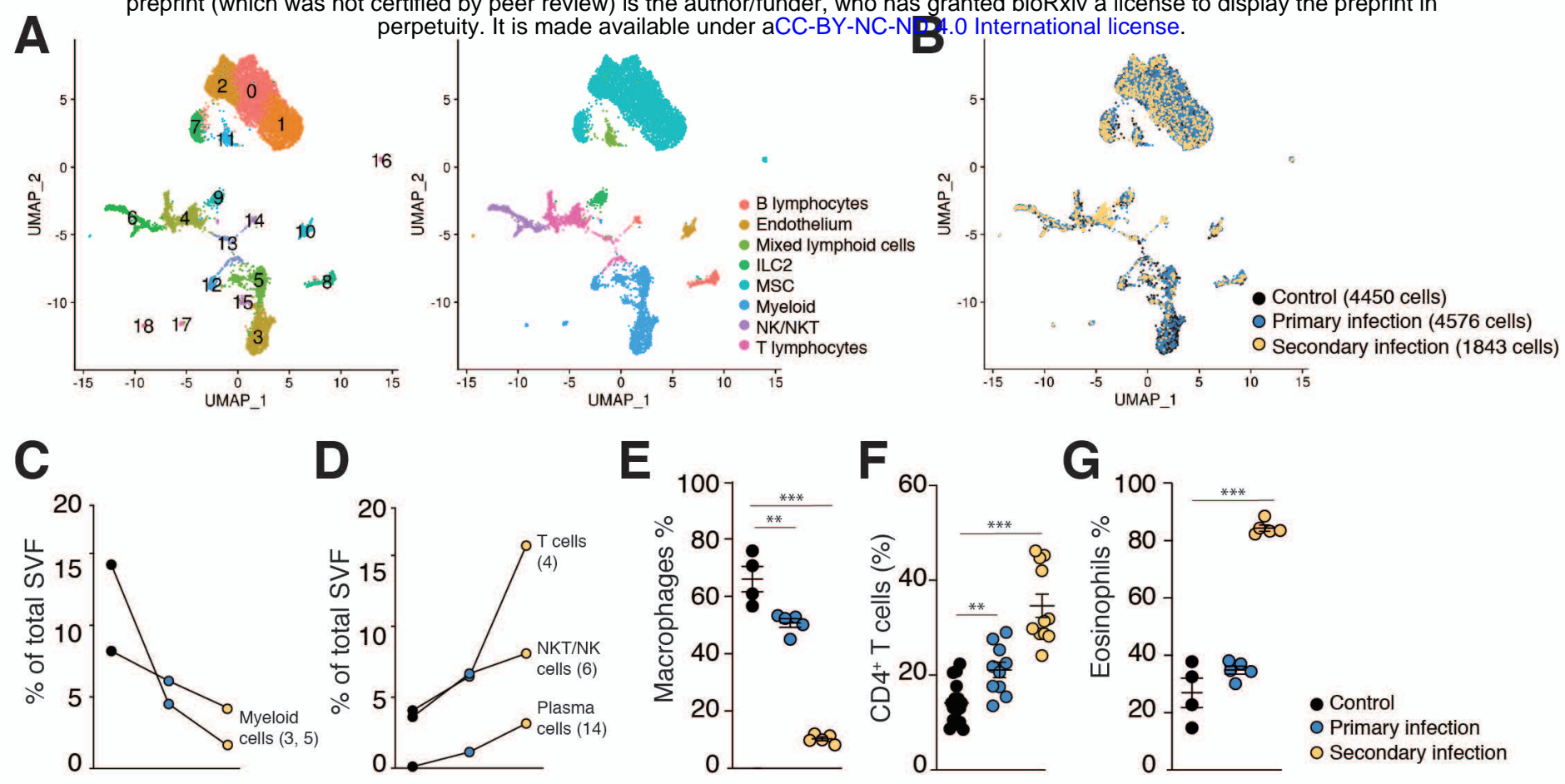

H
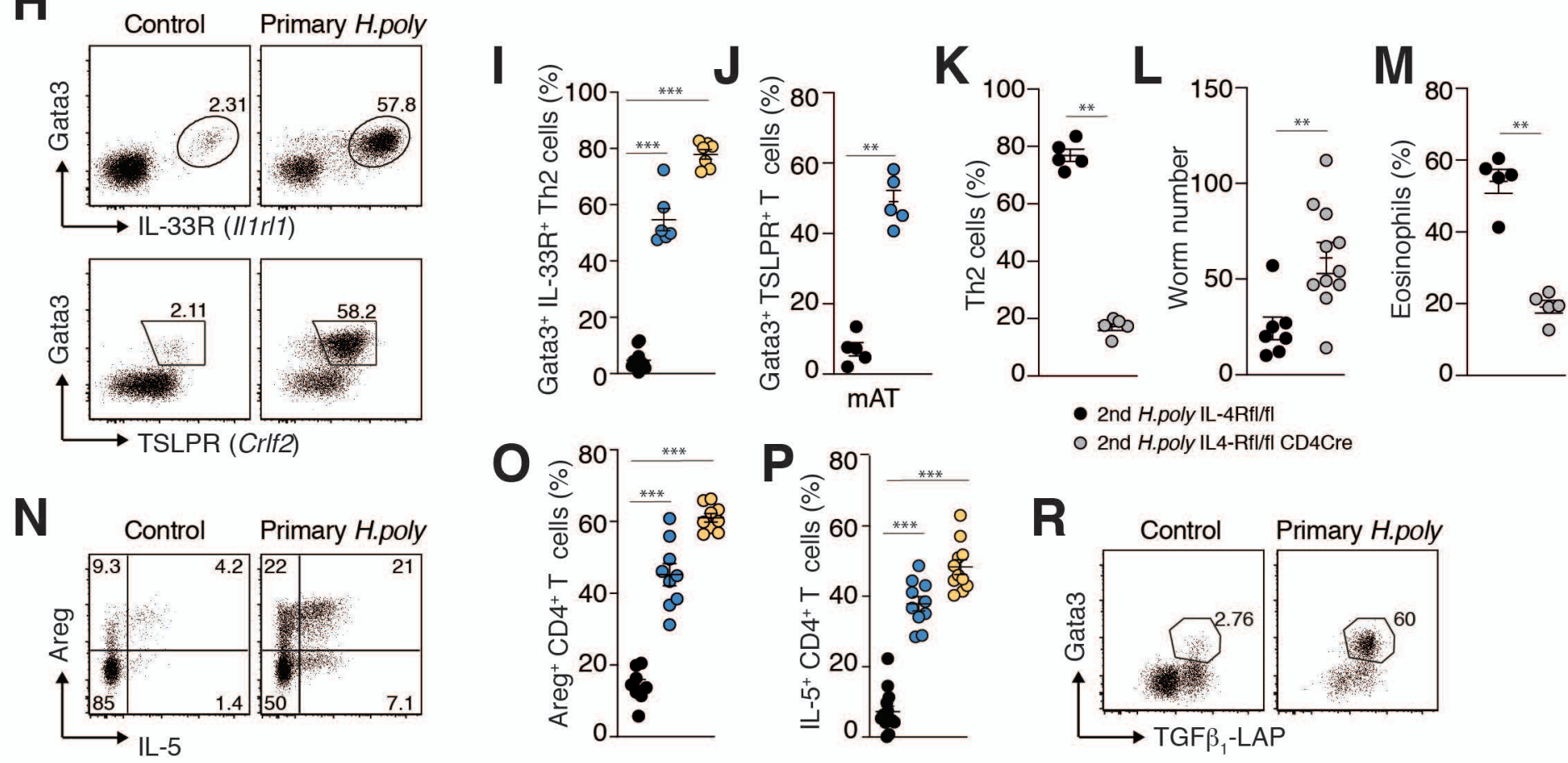

Figure 2 
bioRxiv preprint doi: https://doi.org/10.1101/2022.02.24.481701; this version posted February $26,2022$. The copyright holder for this

preprint (which was not certified by peer review) is the author/funder, who has granted bioRxiv a license to display the preprint in perpetuity. It is made available under aCC-BY-NC-ND 4.0 International license.

\section{Fig 2. Th $2_{\mathrm{RM}}$ cells dominate the mAT $\mathrm{T}$ cell population in $H$. polygyrus infection.}

(A, B) Uniform Manifold Approximation and Projection (UMAP) plots of 10869 SVF cells isolated from mAT depots of control, primary infected and secondary infected mice (one mouse per condition). Unsupervised clustering identified 18 cell groups; plots are colorcoded according to cell cluster and broad identification of cell types (A) or experimental condition (B). (C, D) Changes in immune cell populations after infection (normalized to total cell number in experimental condition). Number in brackets indicate cluster ID from (A). (EG) Frequencies of macrophages $\left(\mathrm{F} 4 / 80^{\text {hi }}\right.$ SiglecF $\left.\mathrm{F}^{\text {low }} \mathrm{CD} 11 \mathrm{~b}^{+}\right)(\mathrm{E}), \mathrm{CD}^{+} \mathrm{TCR} \beta^{+} \mathrm{T}$ cells $(\mathrm{F})$ and eosinophils $\left(\mathrm{F} 4 / 80^{\text {low }}\right.$ SiglecF $\left.{ }^{\text {hi }} \mathrm{CD} 11 \mathrm{~b}^{+}\right)(\mathrm{G})$ in $\mathrm{mAT}$ in control and infected mice. (H-J) Representative FACS plots $(\mathrm{H})$ and quantification $(\mathrm{I}, \mathrm{J})$ of GATA3 ${ }^{+} \mathrm{IL}_{-33 \mathrm{R}^{+}}$and GATA3 ${ }^{+}$ $\mathrm{TSLPR}^{+} \mathrm{Th} 2$ cells (gated on Foxp3-CD4 ${ }^{+} \mathrm{TCR} \beta^{+} \mathrm{CD}^{-} 5^{+}$live cells in lymphocyte gate) in mAT during infection. (K-M) $I l 4 r a^{\mathrm{fl} / \mathrm{fl}} C d 4-C r e$ and $I l 4 r a^{\mathrm{fl} / \mathrm{fl}}$ mice after secondary infection. Frequencies of Th2 cells (IL-33R ${ }^{+}$GATA $^{+}{ }^{+}$FOXP3-CD4 ${ }^{+}{ }^{-T C R} \beta^{+}$) (K), eosinophils (M) (SiglecF ${ }^{\text {hi }}$ SSC-A ${ }^{\text {hi }} \mathrm{CD}^{4} 5^{+}$) and worm numbers in small intestine (L). (N-P) Representative FACS plots $(\mathrm{N})$ and quantification of Areg (O) and IL-5 (P) expression by $\mathrm{mAT} \mathrm{CD4}^{+} \mathrm{T}$ cells (as proportion of $\mathrm{CD} 4^{+} \mathrm{TCR} \beta^{+}$Foxp $3^{-} \mathrm{CD} 45^{+}$live cells in lymphocyte gate) during infection. (R) TGF $\beta_{1}$-LAP expression by mAT Th2 cells in control and infected mice (gated on Foxp3$\mathrm{CD} 4^{+} \mathrm{TCR} \beta^{+} \mathrm{CD} 45^{+}$live cells in lymphocyte gate).

Dots represent BR and error bars represent SEM from BR (E-G, I-M, O, P). Data combined from 2-3 independent experiments (F, I, O, P), representative of 2-3 experiments (E, G, J-M), or from one experiment (A-D, R). 
bioRxiv preprint doi: https://doi.org/10.1101/2022.02.24.481701; this version posted February 26, 2022. The copyright holder for this A preprint (which was not certified by peer review) is the thor/funder, who has granted bioRxiv a license to display the preprint in
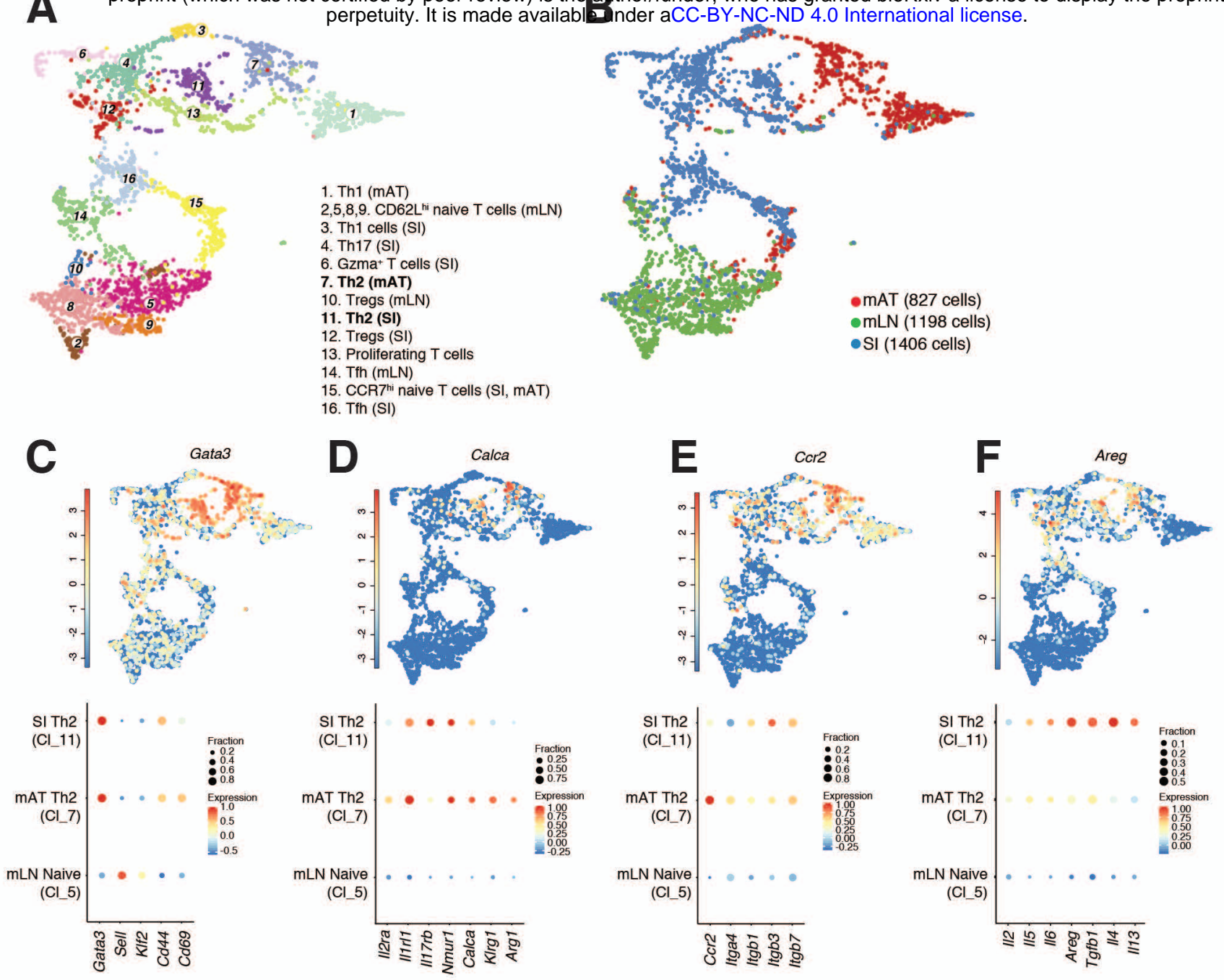

G
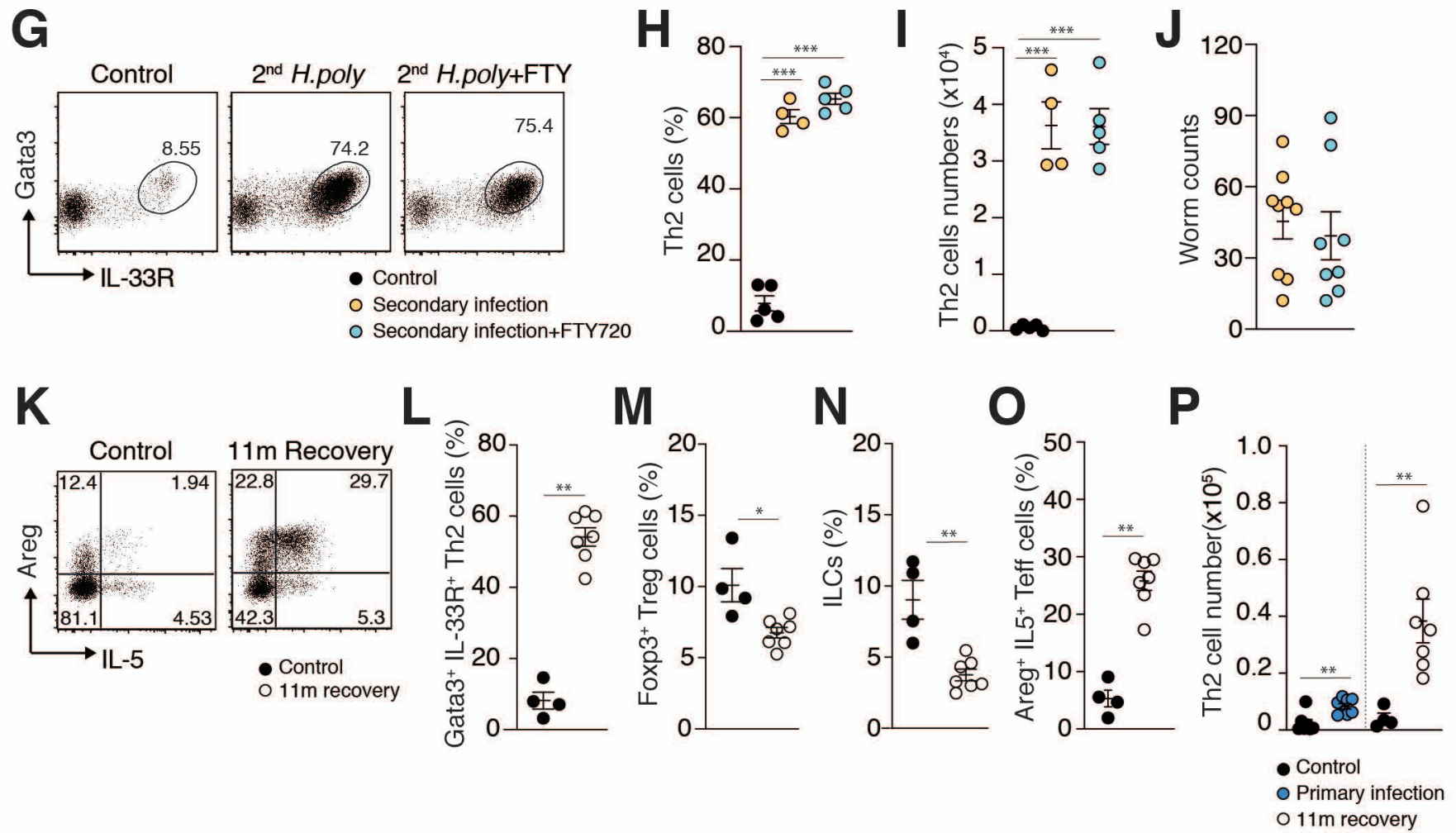
Fig 3. Permanent remodelling of the mAT lymphoid niche after $H$. polygyrus infection.

$(\mathrm{A}, \mathbf{B})$ UMAP plots of $\mathrm{CD} 4^{+} \mathrm{TCR} \beta^{+} \mathrm{T}$ cells sorted from $\mathrm{mLN}, \mathrm{mAT}$ and SI of control, primary and secondary infected mice. Unsupervised clustering distinguished 16 cell groups; plots are color-coded according to cell identity (A) or tissue of origin (B). (C-F). UMAP plots indicating $\log 2$ normalized expression of selected gene (upper panels) and clusterspecific gene expression shown as dot plots (lower panels), where color represents the zscore of the mean expression across clusters and dot size represents the fraction of cells in the cluster expressing the selected gene. (G-J). Mice were subjected to secondary infection and treated with FTY720 throughout the infection where indicated. Representative FACS plots (G), percentages (H) and numbers (I) of GATA3 ${ }^{+} \mathrm{IL}^{-33 \mathrm{R}^{+}}$Th2 cells (gated on Foxp3- $3^{-} \mathrm{TCR} \beta^{+}$ $\mathrm{CD}^{+} 5^{+}$live cells in lymphocyte gate). Worm counts from small intestine (J). (K, $\left.\mathbf{O}\right)$. Representative FACS plot (K) and frequencies (O) of mAT IL- $5^{+}$Areg $^{+}$T cells (gated on Foxp3- CD4 $^{+} \mathrm{TCR}^{+} \mathrm{CD}^{+} 5^{+}$live cells in lymphocyte gate). (L-N) Frequencies of mAT GATA3 $^{+} \mathrm{IL}_{-3} 3 \mathrm{R}^{+} \mathrm{Th} 2$ cells (gated on ${ }^{+}$Foxp3- $^{-} \mathrm{CD} 4^{+}$TCR $\beta C D 45^{+}$live cells in lymphocyte gate), Foxp $3^{+}$Treg cells (gated on $\mathrm{CD}^{+} \mathrm{TCR} \beta^{+} \mathrm{CD} 45^{+}$live cells in lymphocyte gate) and ILC (gated on Lin- CD45 $5^{+}$Thy $1^{+}$live cells in lymphocyte gate; see Methods). (P) Comparison of Th2 numbers in mAT during primary infection and 11 months recovery.

Dots represent BR and error bars represent SEM from BR (H-J, L-P). Data combined from 23 independent experiments (A-F, J, P) or representative of 2-3 experiments (G-I, K-O). 
bioRxiv preprint doi: https://doi.org/10.1101/2022.02.24.481701; this version posted February 26, 2022. The copyright holder for this

preprint (which was not certified by peer review) is the author/funder, who has granted bioRxiv a license to display the preprint in

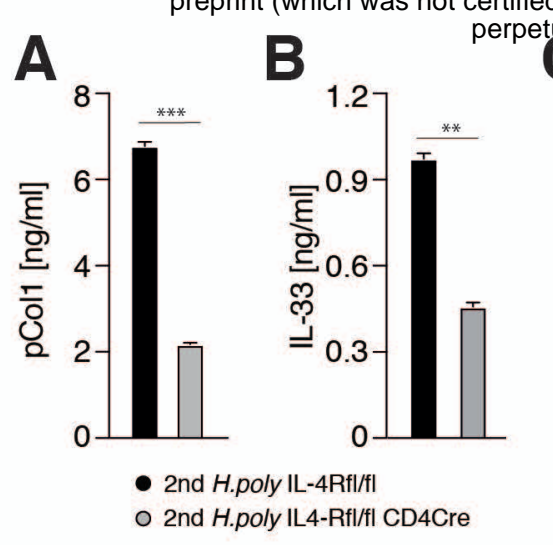

C'

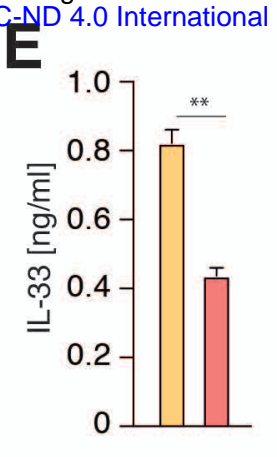

$\mathbf{F}$
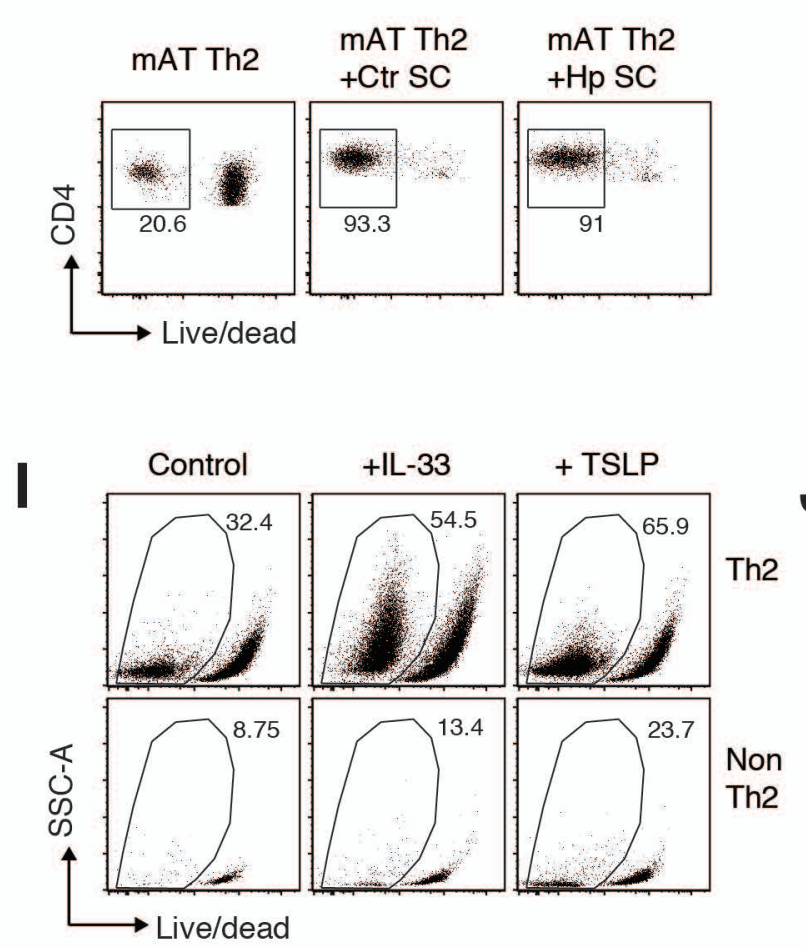

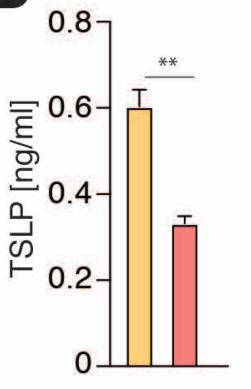

O 2nd H.poly

2nd H.poly+aCD4

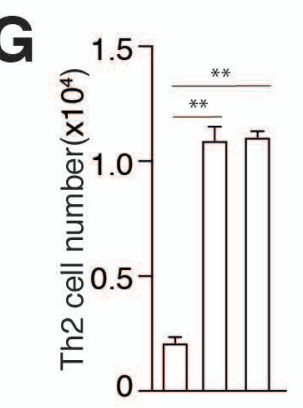

$\mathrm{Ctr} \mathrm{SC}-+-$

Hp SC - - +

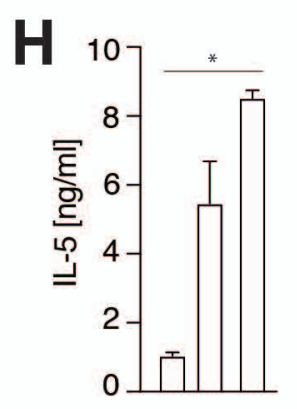

Ctr SC - + -

Hp SC - - +
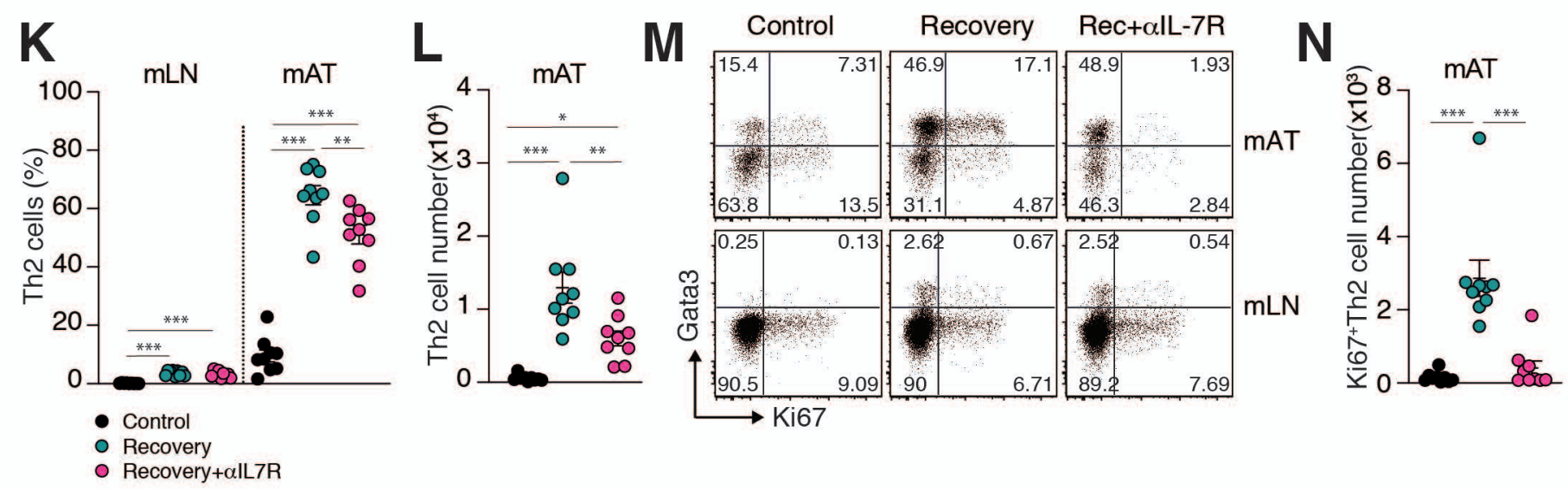

Figure 4 


\section{Fig 4. Interdependence of $\mathrm{mAT}$ Th2 $2_{\mathrm{RM}}$ and SC.}

(A, B) Secretion of pCol1 (A) and IL-33 (B) by isolated mAT SC of $I l 4 r a^{\mathrm{fl} / \mathrm{fl}} C d 4-C r e$ and $I l 4 r a^{\mathrm{fl} / \mathrm{fl}}$ mice after secondary infection. (C-E) pCol1 (C), TSLP (D) and IL-33 (E) production from isolated mAT SC during secondary infection with anti-CD4 depletion where indicated. (F, G) Representative FACS plot (F) and cell number $(\mathrm{G})$ of sorted Th2 cells after 4 days of co-culture with mAT SC isolated from control and infected mice as indicated. (H) IL-5 production by Th2 cells after 4 days of co-culture with $\mathrm{mAT} \mathrm{SC}$ as in (F). (I, J). Th2 cells $\left(\mathrm{CD}^{+} \mathrm{TCR}^{+} \mathrm{IL}^{-\mathrm{eGFP}}{ }^{+}\right.$Foxp3RFP$)$and non-Th2 $\mathrm{CD}^{+} \mathrm{T}^{-}$cells $\left(\mathrm{CD}^{+}{ }^{+} \mathrm{TCR}^{+} \mathrm{IL}^{-\mathrm{eGFP}}{ }^{-}\right.$ Foxp3RFP-) were sorted from mAT and $\mathrm{mLN}$ of infected mice and cultured for 3 - 6 days with addition of IL-33 [50ng/ml] or TSLP [50ng/ml]. FACS plot of mAT Th2 and non-Th2 cells with frequencies of live cells after 6 days of culture (I). Levels of indicated cytokines in the supernatants of mAT Th2 cells after 3 days of culture (J). (K-N) TSLP signalling was blocked with anti-IL-7R $\alpha$ antibody treatment during recovery after primary infection. Frequencies (K) and numbers (L) of Th2 cells (gated on IL-33R ${ }^{+}$GATA3 $^{+}$among CD4 ${ }^{+}$ $\mathrm{TCR} \beta^{+} \mathrm{T}$ cells) in mAT or mLN as indicated. Representative FACS plot (M) and numbers (N) of Ki67 $7^{+}$Th2 cells in mAT.

Dots represent BR $(K, L, N)$, error bars represent SEM from BR $(K, L, N)$ or TR (A-E, G, H, J). Data combined from 2 independent experiments $(K, L, N)$ or representative of 2-3 experiments (A-E, G, H, J). 
bioRxiv preprint doi: https://doi.org/10.1101/2022.02.24.481701; this version posted February 26, 2022. The copyright holder for this

preprint (which was not certified by peer review) is the author/funder, who has granted bioRxiv a license to display the preprint in

A perpetuity. It is matal available under aCC-BY-NC-ND 4.0 International license.
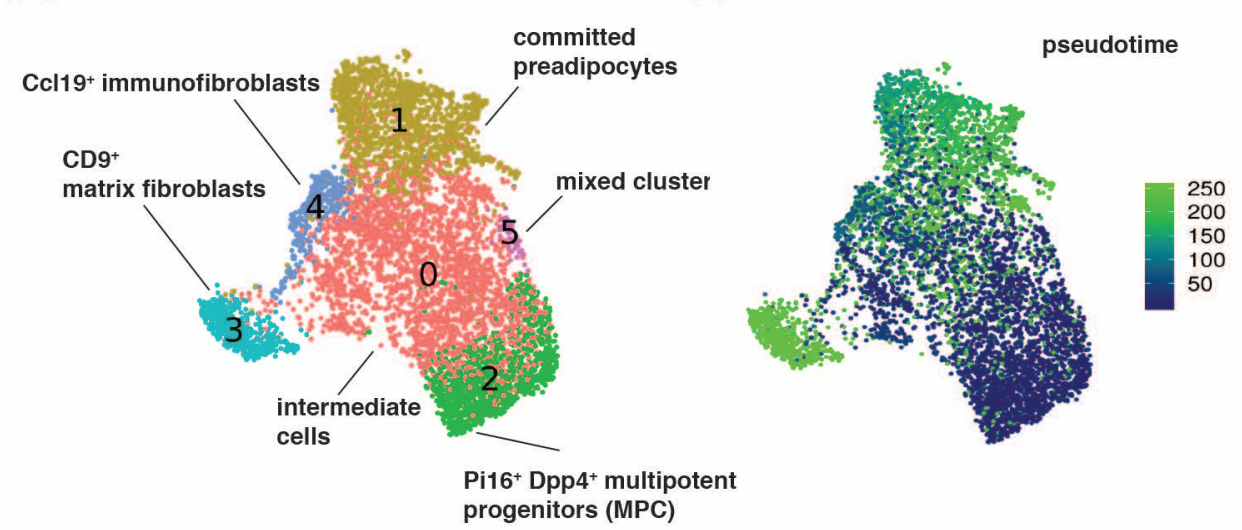

$\mathbf{E}$

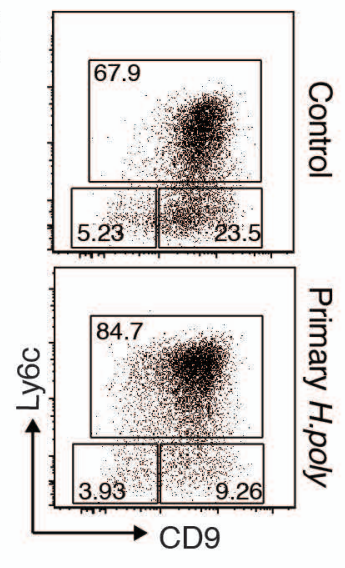

F matrix

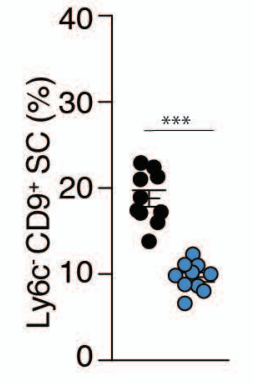

G

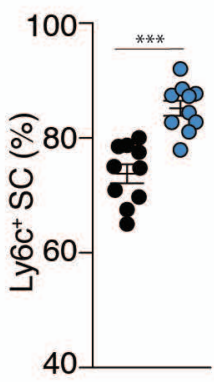

preadipocytes

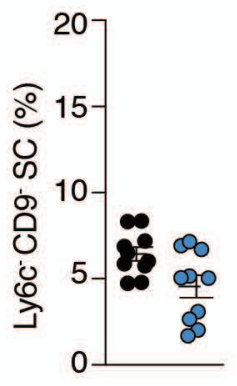

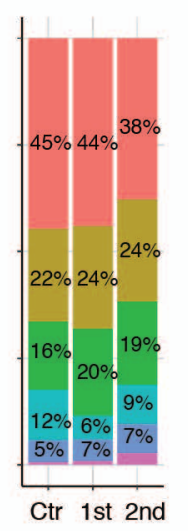

D
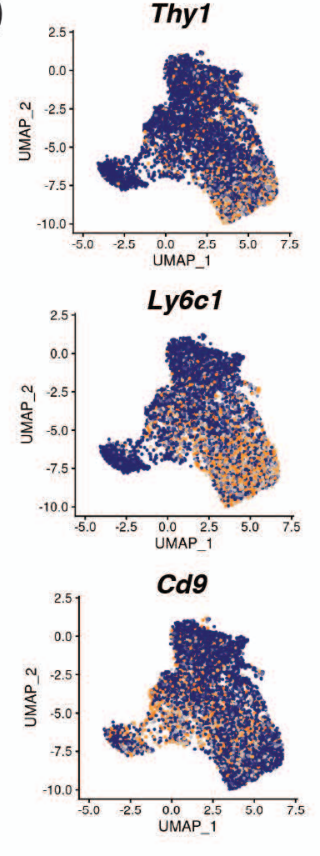

H

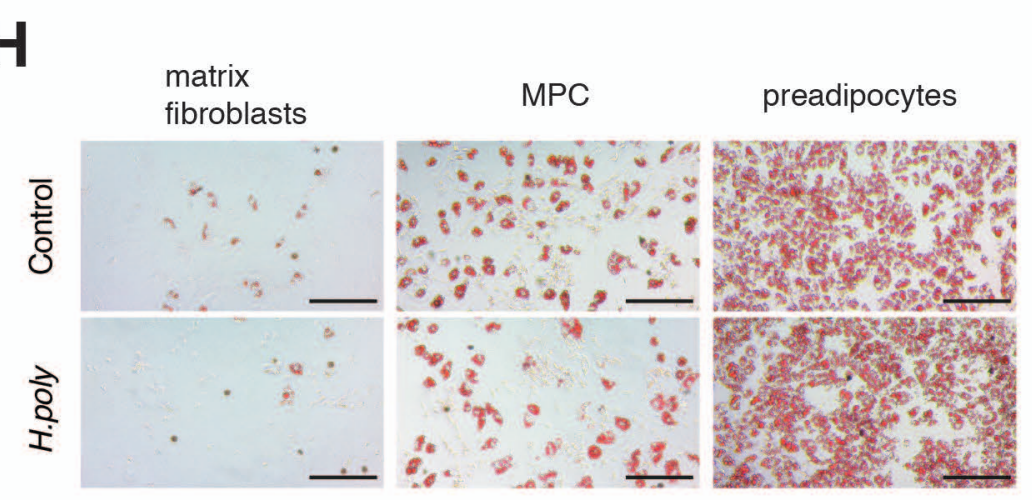

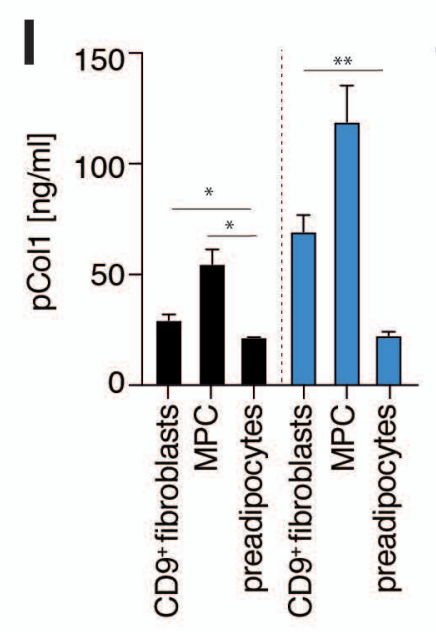

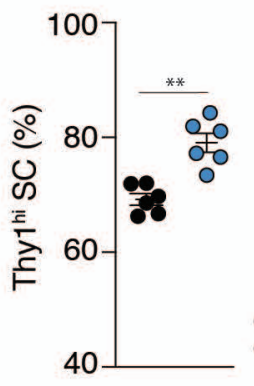

- Control O Primary infection

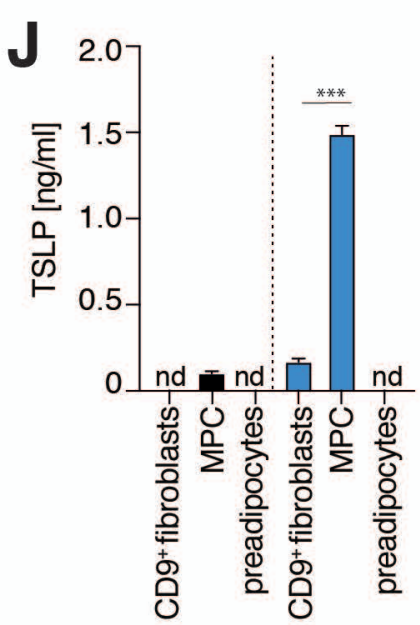

Figure 5 


\section{Fig 5. Expansion of the mAT $D p p 4^{+}$MPC in H. polygyrus infection.}

(A) UMAP plot of 6059 mAT SC from control (2457 cells), primary infected (2640 cells) and secondary infected mice (962 cells). Unsupervised clustering distinguished 6 cell clusters (A); plots are colour-coded according to cell cluster. Identified cell population based on expression of following markers: committed preadipocytes (C1): Icam1, Apoe, Lpl, Fabp4, Pparg; pluripotent progenitors (C2): Dpp4, Anxa3, Cd55, Pi16, Dpt; CD9 ${ }^{+}$profibrotic cells (3): Cd9, Wnt6, Eln, Mgp, Colla1, Col15a1; immunofibroblasts (C4): Cd9, Ccl19. (B) UMAP plot as in A, showing pseudotemporal ordering of cells, setting origin at the centre of C2 (multipotent progenitor cells, MPC). (C) Bar graphs represent contribution of each cluster as in (A) to a total cell pool, split by experimental condition. (D) UMAP plots indicating expression of selected genes. (E, F) Representative FACS plots (E) and quantification (F) of mAT SC populations from control and H. polygyrus infected mice:

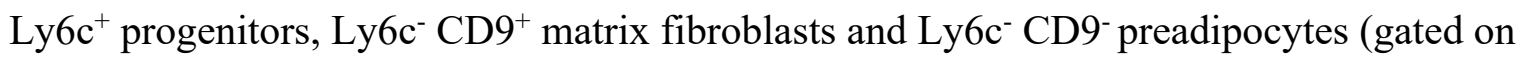
live CD45- CD31- PDGFR $\alpha^{+}$cells). (G) Frequencies of Thy $1^{\text {hi }}$ mAT SC in control and $H$. polygyrus infected mice (gated on live CD45- CD31- PDGFR $\alpha^{+}$cells). (H). mAT SC were sorted into Ly $6 \mathrm{c}^{+}$progenitors, $\mathrm{Ly}^{-} \mathrm{c}^{-} \mathrm{CD}^{+}$matrix fibroblasts and $\mathrm{Ly}^{6} \mathrm{c}^{-} \mathrm{CD}^{-}$preadipocytes and subjected to adipogenic differentiation (see Methods). Representative images on day 6 showing accumulation of lipid droplets. Scale bar $200 \mu \mathrm{m}$. (I, J) pCol1 (I) and TSLP (J) levels measured in supernatants from overnight culture of cells sorted as in $(\mathrm{H})$.

Dots represent BR $(F, G)$, error bars represent SEM from BR (F, G) or TR (I, J). Data combined from 2 independent experiments $(\mathrm{F})$, representative of two independent experiments (G, H-J) or from one experiment (A-D). 
bioRxiv preprint doi: https://doi.org/10.1101/2022.02.24.481701; this version posted February 26, 2022. The copyright holder for this

preprint (which was not certified by peer review) is the author/funder, who has granted bioRxiv a license to display the preprint in

A

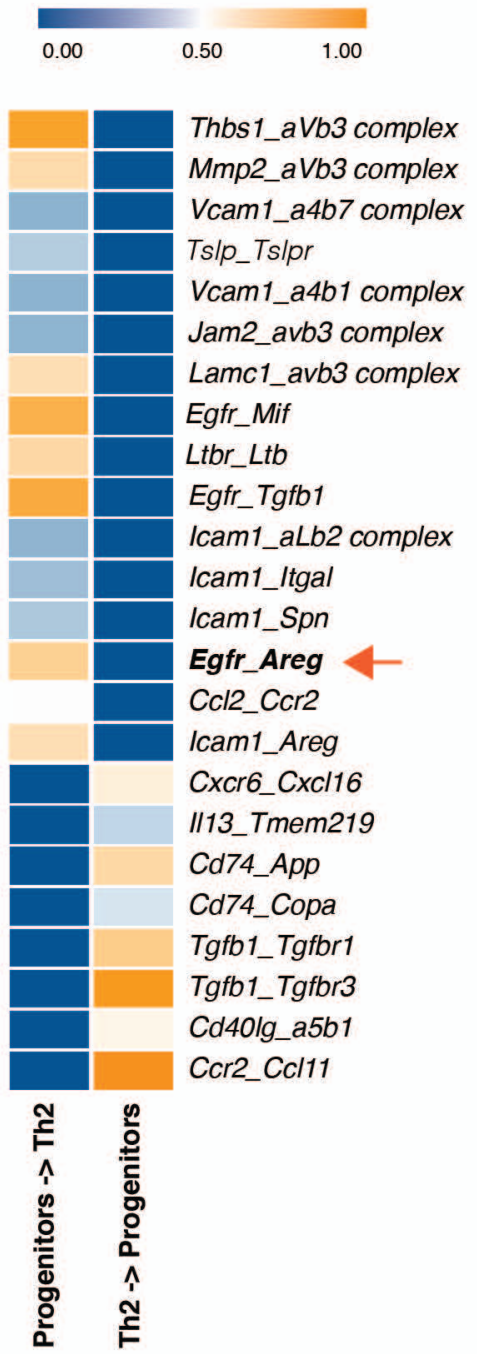

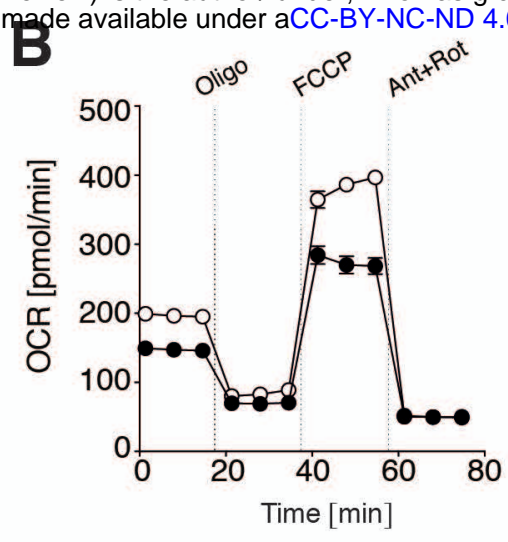
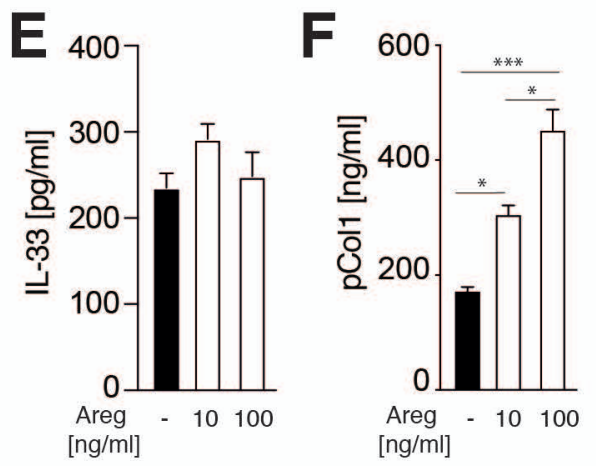

H

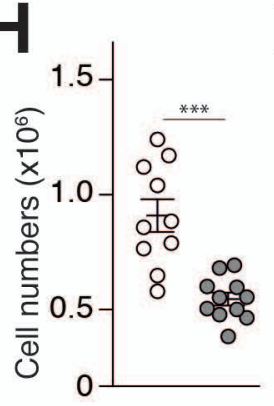

K $\mathrm{Cre+}+\mathrm{Cre}-$

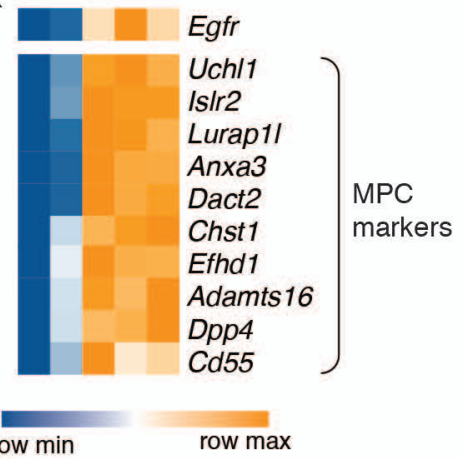

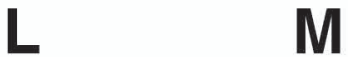

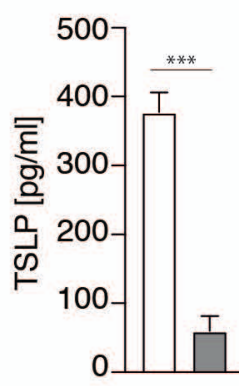

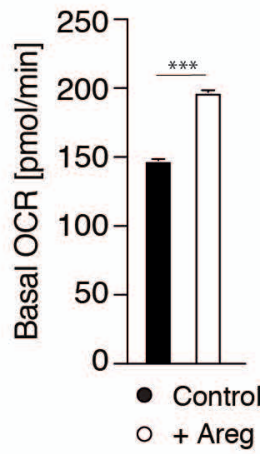

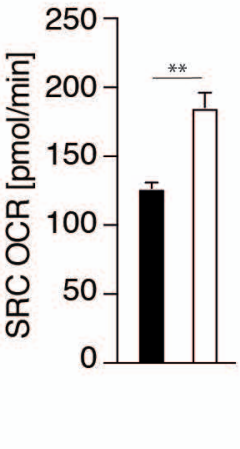

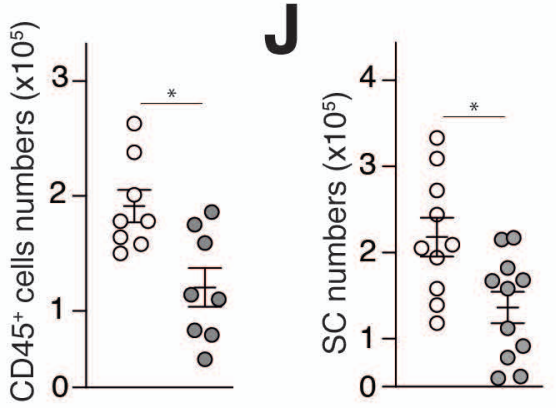

O Egfrfl/fl

- Egfrfl/fl Pdgfr-Cre
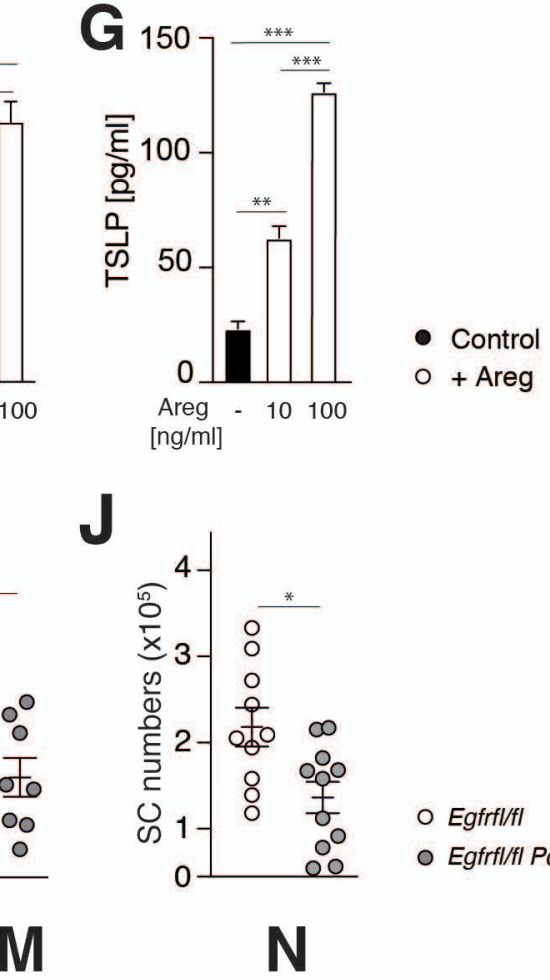

N
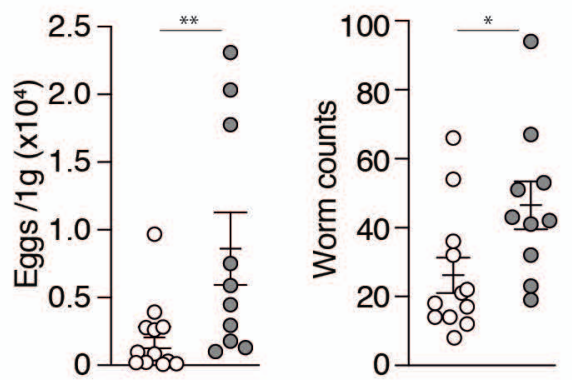
Fig 6. Areg supports mitochondrial respiration and TSLP production by mAT SC.

(A) CellPhone analysis of ligand-receptor pairs between mAT Th2 cells and MPC. (B-D) mAT SC were subjected to 3 days of adipogenic differentiation in the presence of Areg $[100 \mathrm{ng} / \mathrm{ml}]$ where indicated. OCR was measured at baseline and after Oligomycin (Oligo), FCCP and Rotenone/Antimycin (Rot/Ant) injections (B). Baseline OCR (C) and SRC (difference between response to FCCP and basal OCR) (D). (E-G) mAT SC were subjected to 4-5 days of adipogenic differentiation in the presence of Areg as indicated. Levels of IL-33 (E), pColl (F) and TSLP (G) were measured in the supernatants. (H-J) Total SVF cell counts $(\mathrm{H})$, immune cell counts (gated on live $\mathrm{CD}^{+} 5^{+} \mathrm{CD} 31^{-}$cells) (I) and SC counts (gated on live $\mathrm{CD}^{-}$CD31-PDGFR $\left.^{+}\right)(\mathrm{J})$ in mAT of $E g f r^{\mathrm{fl} / \mathrm{fl}}$ and $E g f r^{\mathrm{fl} / \mathrm{fl}}-P d g f r a-C r e$ mice. $(\mathbf{K})$ Expression pattern of MPC markers in RNAseq dataset from mAT SC isolated from H. polygyrus infected $E g f r^{\mathrm{fl} / \mathrm{fl}}$ and $E g f r^{\mathrm{fl} / \mathrm{fl}}-P d g f r a-C r e$ mice (sorted CD31- CD45- PDGFR $\alpha^{+}$). (L). Purified mAT SC from $H$. polygyrus infected $E g f r^{\mathrm{fl} / \mathrm{fl}}$ and $E g f r^{\mathrm{fl} / \mathrm{fl}}-P d g f r a-C r e$ mice were cultured overnight and TSLP levels were measured in the supernatants. (M, N) Eggs in the caecum content (M) and worms in the small intestine (N) were enumerated in $E g f r^{\mathrm{fl} / f l}$ and $E g f r^{\mathrm{fl} / \mathrm{fl}}$ Pdgfra-Cre mice with primary infection.

Dots represents BR (H-J, L-N), error bars represent SEM from BR (B-D, F, H-J, L-N) or TR (E, G, L). Data combined from 2 independent experiments (H-J, M, N), representative of two to three independent experiments $(B-G)$ or from one experiment $(A, K, L)$. 
bioRxiv preprint doi: https://doi.org/10.1101/2022.02.24.481701; this version posted February 26, 2022. The copyright holder for this preprint (which was not certified by peer review) is the author/funder, who has granted bioRxiv a license to display the preprint in A perpetuity. It is made available under aCC-BY-NC-ND 4.0 International license.

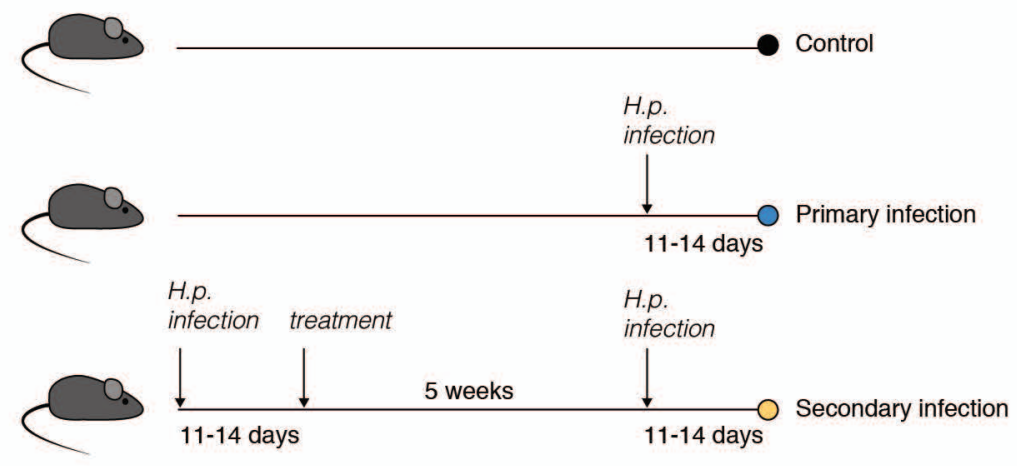


bioRxiv preprint doi: https://doi.org/10.1101/2022.02.24.481701; this version posted February 26, 2022. The copyright holder for this

preprint (which was not certified by peer review) is the author/funder, who has granted bioRxiv a license to display the preprint in perpetuity. It is made available under aCC-BY-NC-ND 4.0 International license.

Fig. S1.

(A) Schematic representation of $H$. polygyrus infection model. 
bioRxiv preprint doi: https://doi.org/10.1101/2022.02.24.481701; this version posted February 26, 2022. The copyright holder for this

preprint (which was not certified by peer review) is the author/funder, who has granted bioRxiv a license to display the preprint in perpetuity. It is made available under aCC-BY-NC-ND 4.0 International license.

A

Cd3e (T cells)

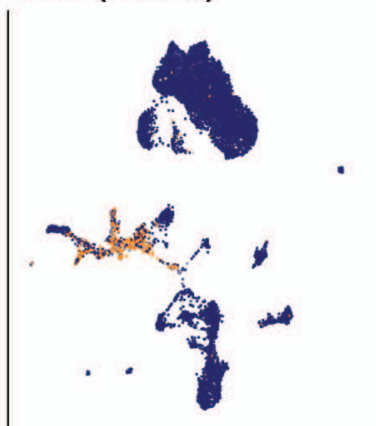

Cd79a (B cells)

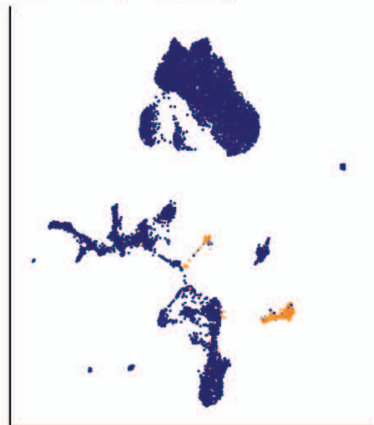

Lyz2 (Myeloid cells)

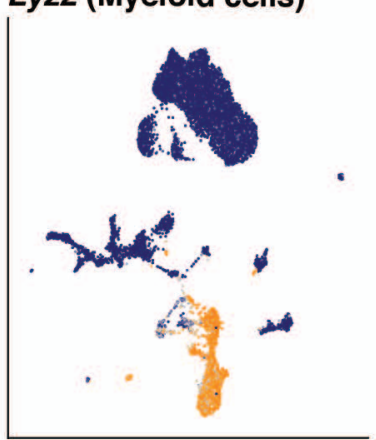

Gata3 (Th2, ILC2)

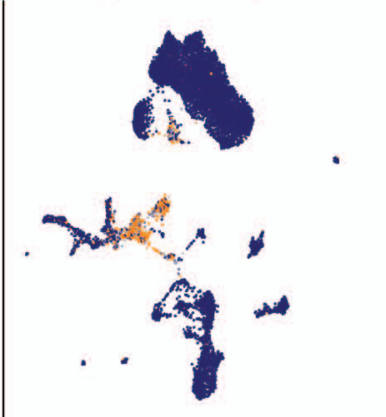

Mzb1 (B1 cells)

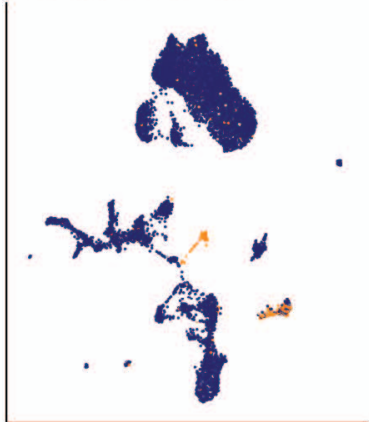

Pecam1 (Endothelial cells) Ptprc (Immune cells)

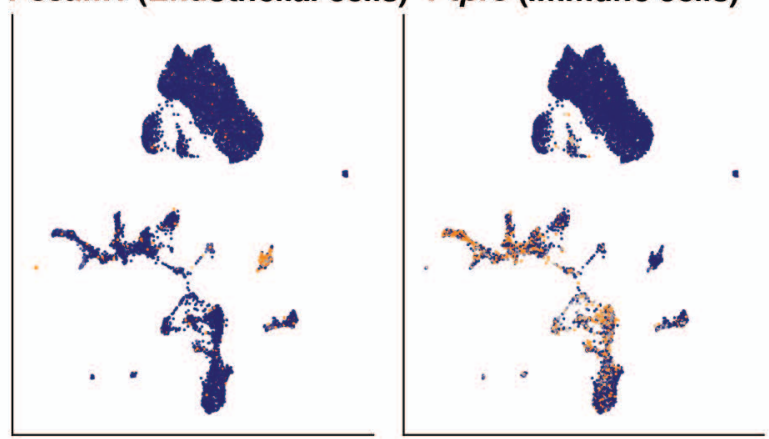

Nkg7 (NK, NKT)

B

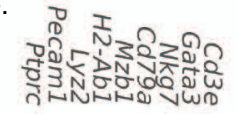

0

4 
bioRxiv preprint doi: https://doi.org/10.1101/2022.02.24.481701; this version posted February $26,2022$. The copyright holder for this

preprint (which was not certified by peer review) is the author/funder, who has granted bioRxiv a license to display the preprint in perpetuity. It is made available under aCC-BY-NC-ND 4.0 International license.

Fig. S2. Marker gene expression pattern in SVF scRNASeq data from mAT

(A) UMAP plots of SVF cells isolated from mAT depots of control, primary infected and secondary infected mice as in Fig. 2A, expression of key genes used for identification of cell types is highlighted. (B) Heatmap showing selected key markers used for identification of cells in the clusters in the SVF scRNASeq dataset. Numbers indicate cluster identity. Data from one experiment. 
bioRxiv preprint doi: https://doi.org/10.1101/2022.02.24.481701; this version posted February 26, 2022. The copyright holder for this preprint (which was not certified by peer review) is the author/funder, who has granted bioRxiv a license to display the preprint in
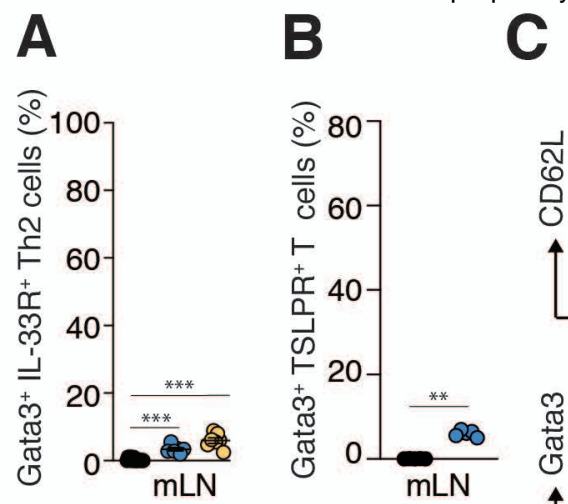

- Control

O Primary infection
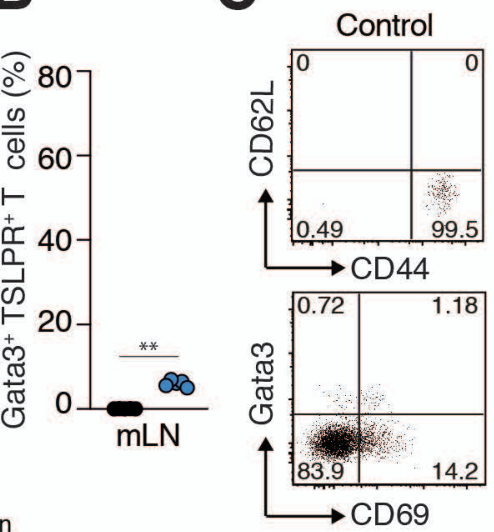

Primary H.poly

o Secondary infection

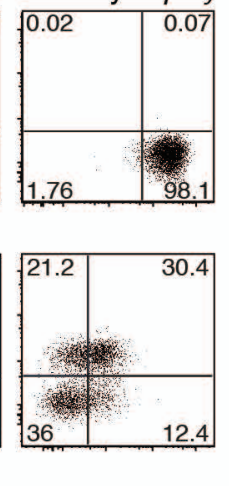


bioRxiv preprint doi: https://doi.org/10.1101/2022.02.24.481701; this version posted February $26,2022$. The copyright holder for this

preprint (which was not certified by peer review) is the author/funder, who has granted bioRxiv a license to display the preprint in perpetuity. It is made available under aCC-BY-NC-ND 4.0 International license.

Fig. S3. Characteristics of $\mathrm{T}$ cells in $\mathrm{mLN}$ and $\mathrm{mAT}$ of $H$. polygyrus infected mice $($ A, B $)$ GATA3 $^{+} \mathrm{IL}_{-33 R^{+}}$(A) and GATA3 ${ }^{+} \mathrm{TSLPR}^{+}$(B) Th2 cells (gated on Foxp3-CD4 ${ }^{+}$ $\mathrm{TCR} \beta^{+} \mathrm{CD}_{4} 5^{+}$live cells in lymphocyte gate) in mLN during H. polygyrus infection. (C) Representative FACS plot of CD44, CD62L and CD69 expression in mAT Th2 cells in control and H. polygyrus infected mice. For CD44, CD62L cells were gated on Foxp3$\mathrm{GATA}^{+} \mathrm{TCR}^{+} \mathrm{CD}^{+} \mathrm{CD}^{+} 5^{+}$live cells in lymphocyte gate, for CD69 cells were gated on live Foxp3- TCR $^{+} \mathrm{CD}^{+} \mathrm{CD}^{+} 5^{+}$cells in lymphocyte gate.

Dot represents BR and error bars represent $\operatorname{SEM}$ from BR (A, B). Data combined from 2 independent experiments $(A)$ or representative of 2 experiments $(B, C)$. 
bioRxiv preprint doi: https://doi.org/10.1101/2022.02.24.481701; this version posted February 26, 2022. The copyright holder for this preprint (which was not certified by peer review) is the author/funder, who has granted bioRxiv a license to display the preprint in

A

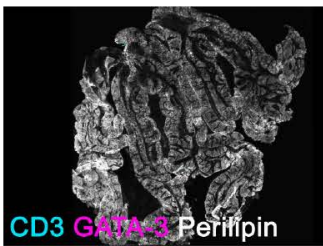
mAT Control
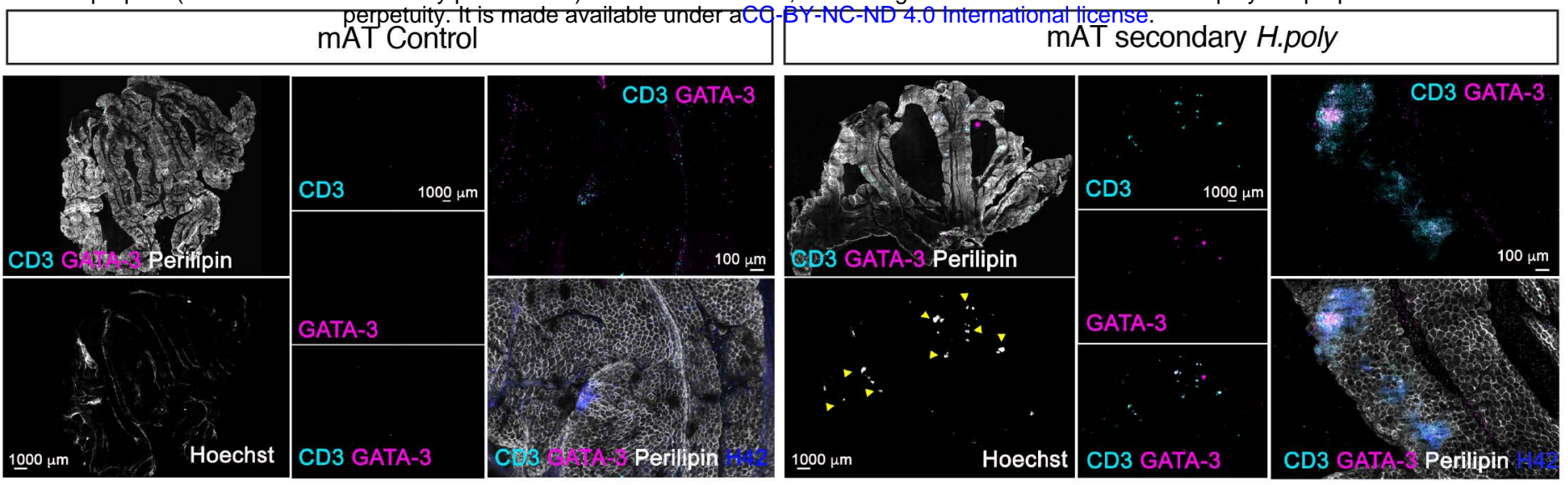

B

D3 GATA- Perilipin

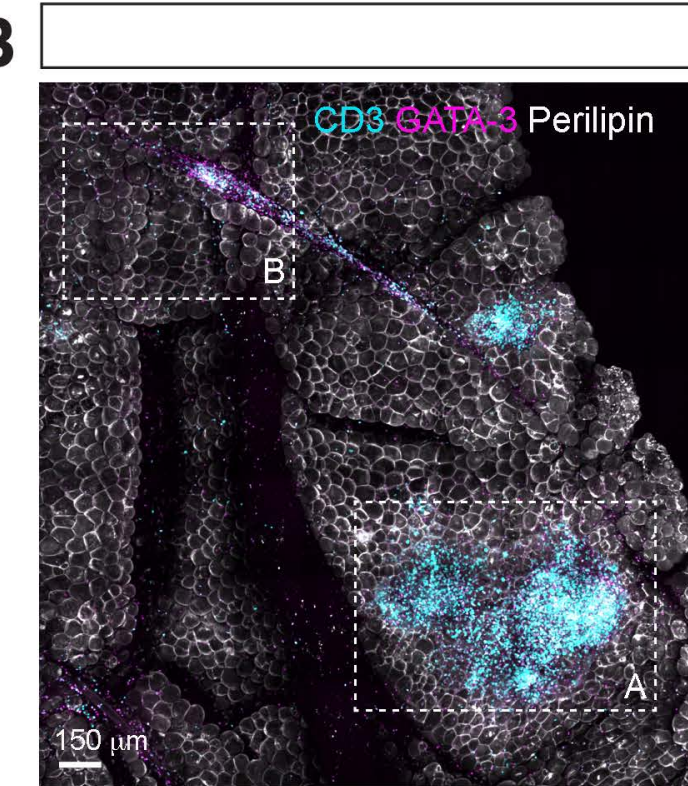

mATsecondary H.poly

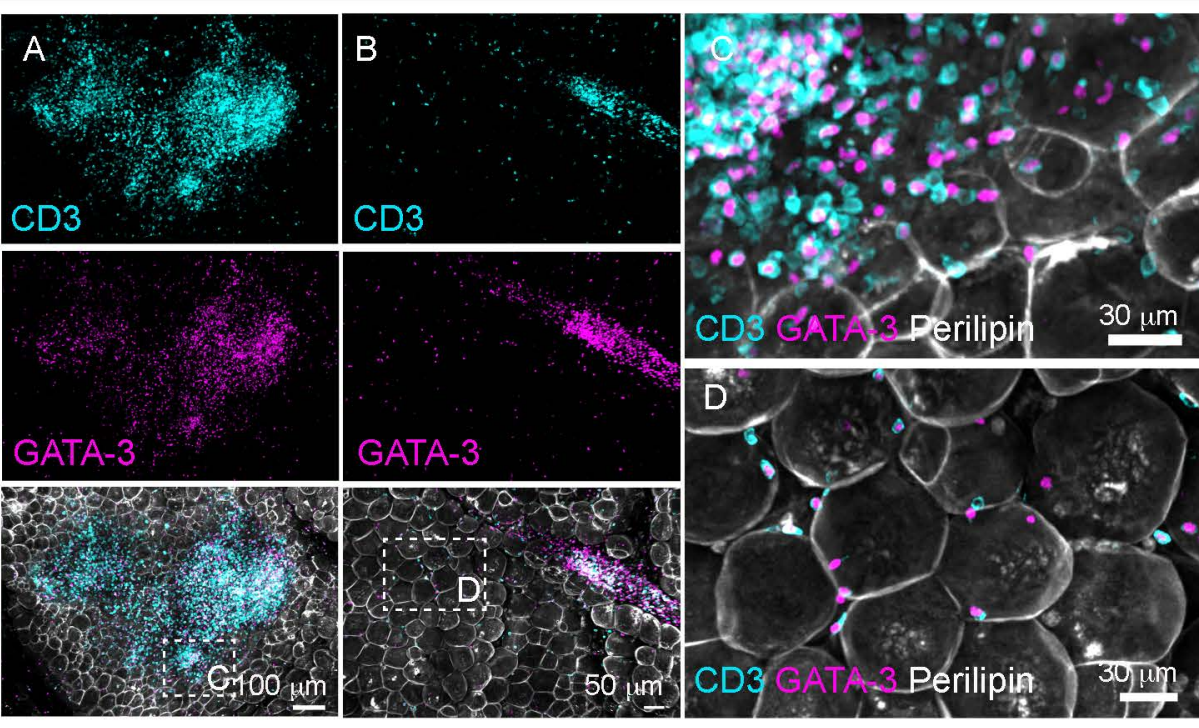

C

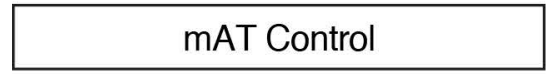

CD3 GATA-3

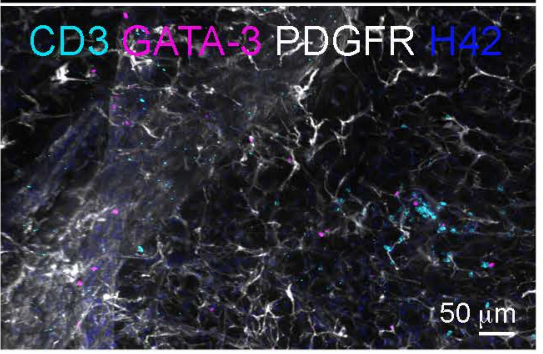

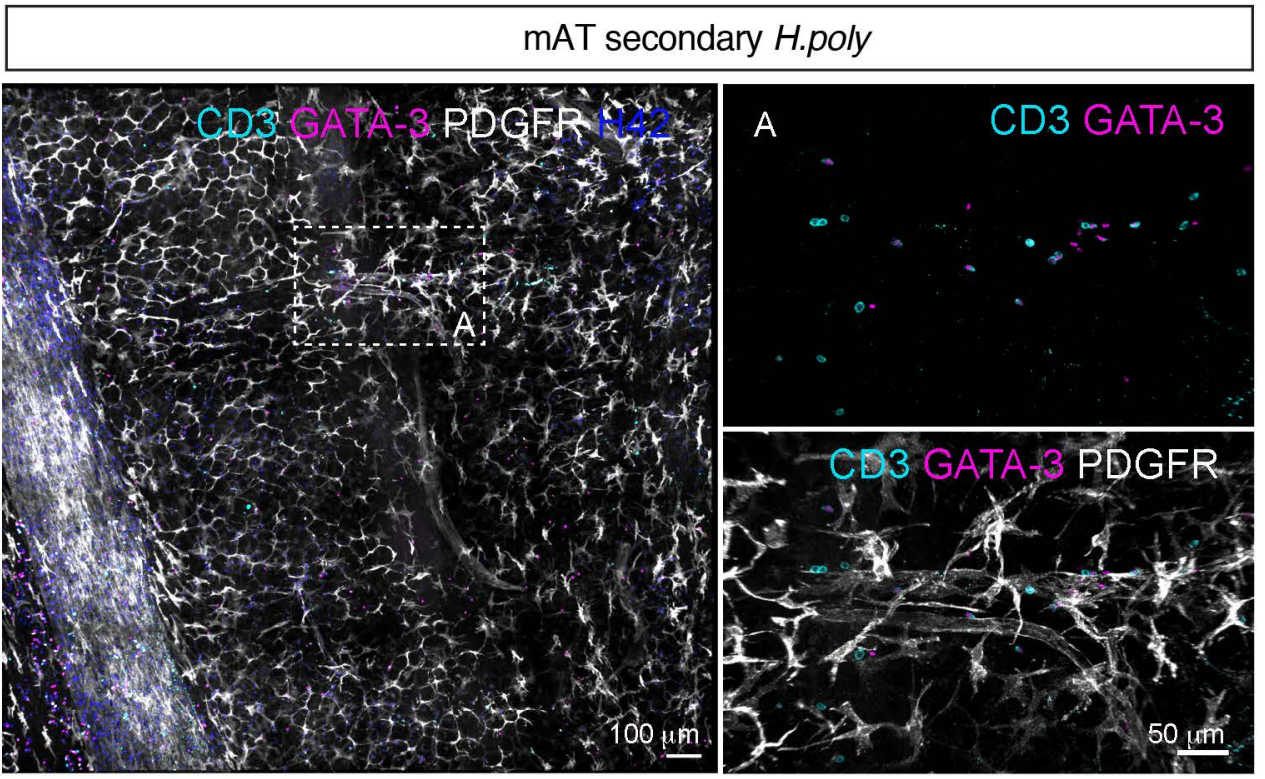


bioRxiv preprint doi: https://doi.org/10.1101/2022.02.24.481701; this version posted February $26,2022$. The copyright holder for this

preprint (which was not certified by peer review) is the author/funder, who has granted bioRxiv a license to display the preprint in perpetuity. It is made available under aCC-BY-NC-ND 4.0 International license.

\section{Fig. S4. Localization of $\mathrm{Th}_{\mathrm{RM}}$ cells in $\mathrm{mAT}$ in $H$. polygyrus infection}

(A-C) Whole mount images of mAT from control and secondary $H$. polygyrus infection stained for CD3, GATA3, Perilipin-1, PDGFR $\alpha$ and nuclear staining (Hoechst) as indicated.

Yellow arrows indicate tertiary lymphoid structures with the mAT (A).

Data from one experiment. 
bioRxiv preprint doi: https://doi.org/10.1101/2022.02.24.481701; this version posted February 26, 2022. The copyright holder for this

preprint (which was not certified by peer review) is the author/funder, who has granted bioRxiv a license to display the preprint in

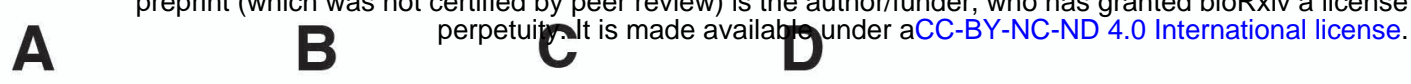
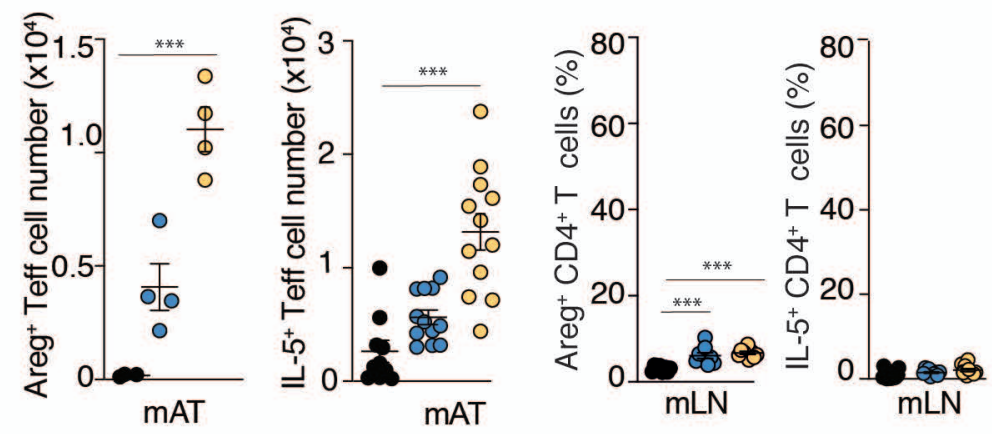

- Control

O Primary infection

o Secondary infection

E

Areg

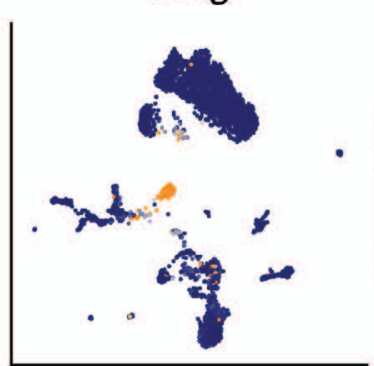

Tgfb1
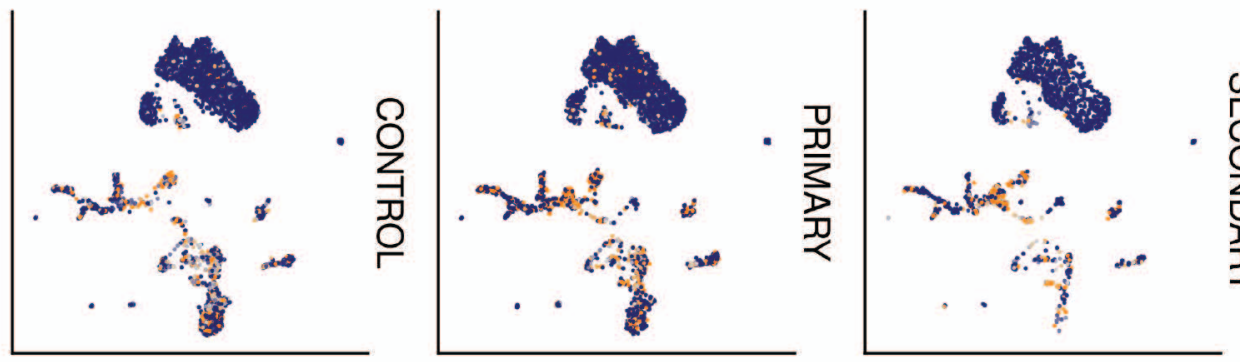

Areg $\operatorname{Tgfb}^{+}$cells

$\mathbf{F}$

G
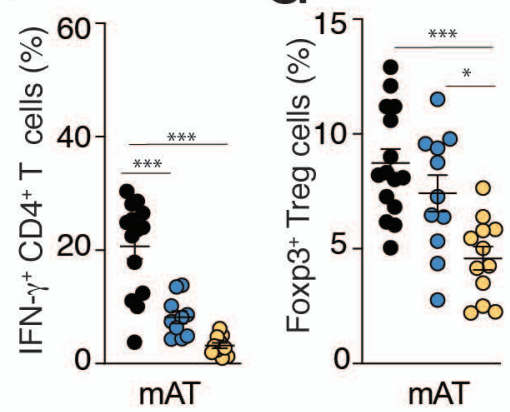

H

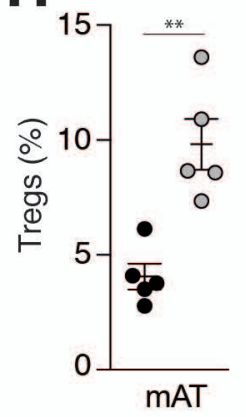

- 2nd H.poly IL-4Rfl/fi

O 2nd H.poly IL4-Rfl/fl CD4Cre 
bioRxiv preprint doi: https://doi.org/10.1101/2022.02.24.481701; this version posted February $26,2022$. The copyright holder for this

preprint (which was not certified by peer review) is the author/funder, who has granted bioRxiv a license to display the preprint in perpetuity. It is made available under aCC-BY-NC-ND 4.0 International license.

\section{Fig. S5. Th2 ${ }_{\mathrm{RM}}$ cell cytokine production in $H$. polygyrus infection}

$(\mathbf{A}, \mathbf{B})$ Numbers of $\operatorname{Areg}^{+}(\mathrm{A})$ and $\mathrm{IL}_{-} 5^{+}(\mathrm{B})$ effector T cells in mAT in control and $H$. polygyrus infected mice. (C, D) Frequencies of $\operatorname{Areg}^{+}(\mathrm{C})$ and $\mathrm{IL}-5^{+}(\mathrm{D})$ effector T cells in $\mathrm{mLN}$ in control and H. polygyrus infected mice (gated on Foxp3 ${ }^{-} \mathrm{CD} 4^{+} \mathrm{TCR} \beta^{+} \mathrm{CD} 45^{+}$live cells in lymphocyte gate). (E) UMAP of $T g f b 1$ and Areg expression in cells from the scRNASeq SVF dataset as in Fig 2A split by experimental condition. Bar graph shows cluster distribution of double positive $T g f b 1$ and Areg expressing cells ( $>0.5$ normalized expression level) in scRNASeq SVF dataset. (F) Frequencies of IFN- $\gamma^{+}$effector T cells in mAT in $H$. polygyrus infection (as proportion of Foxp3- $3^{-} 4^{+} \mathrm{TCR} \beta^{+} \mathrm{CD}^{4} 5^{+}$live cells in lymphocyte gate). (G) Frequencies of mAT Foxp $3^{+}$Treg cells as a proportion of $\mathrm{CD} 4^{+} \mathrm{TCR} \beta^{+} \mathrm{CD} 45^{+}$live cells in lymphocyte gate in control and $\mathrm{H}$. polygyrus infected mice. (H) $\mathrm{Il} 4 \mathrm{ra} \mathrm{fl}^{\mathrm{fl} / \mathrm{fl}} \mathrm{Cd} 4-\mathrm{Cre}$ and $I l 4 r a^{\mathrm{fl} / \mathrm{fl}}$ mice were subjected to secondary $H$. polygyrus infection. Frequencies of mAT Treg cells (FOXP $3^{+} \mathrm{CD} 4^{+} \mathrm{TCR} \beta^{+} \mathrm{CD} 45^{+}$cells in lymphocyte gate.)

Dot represents BR and error bars represent SEM from BR (A-D, F-H). Data combined from 23 independent experiments (B-D, F, G), representative of 2 experiments $(A, H)$, or from one experiment (E). 
bioRxiv preprint doi: https://doi.org/10.1101/2022.02.24.481701; this version posted February 26, 2022. The copyright holder for this preprint (which was not certified by peer review) is the author/funder, who has granted bioRxiv a license to display the preprint in perpetuity. It is made available under aCC-BY-NC-ND 4.0 International license.

A
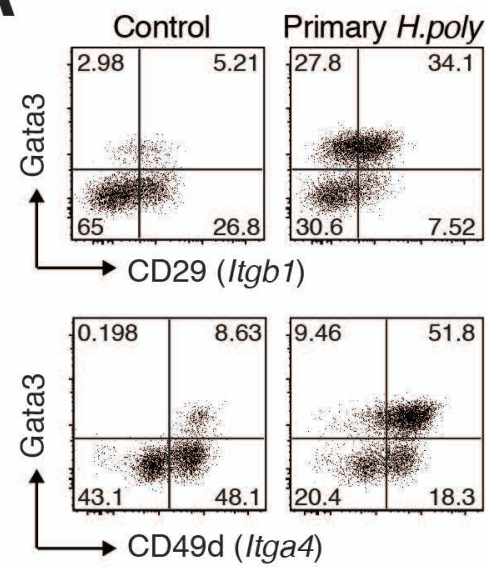
bioRxiv preprint doi: https://doi.org/10.1101/2022.02.24.481701; this version posted February $26,2022$. The copyright holder for this

preprint (which was not certified by peer review) is the author/funder, who has granted bioRxiv a license to display the preprint in perpetuity. It is made available under aCC-BY-NC-ND 4.0 International license.

Fig. S6. Integrin expression pattern on $\mathrm{mAT}$ Th2 $2_{\mathrm{RM}}$ cells in $H$. polygyrus infection

(A) Representative FACS plots of CD29 and CD49d expression by mAT Th2 cells in control and H. polygyrus infected mice (gated on Foxp3- $3^{-} 4^{+} \mathrm{TCR}^{+} \mathrm{CD} 45^{+}$live cells in lymphocyte gate).

Data representative from two experiments. 
A

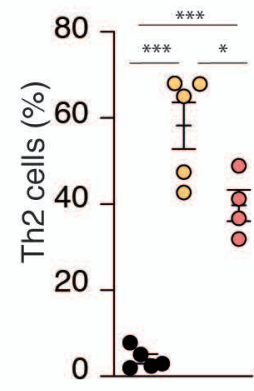

D

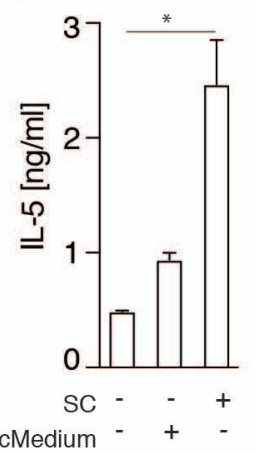

B

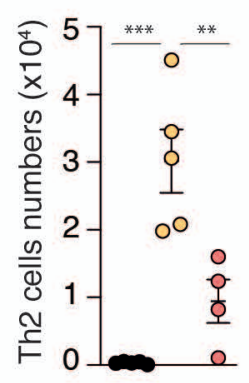

C

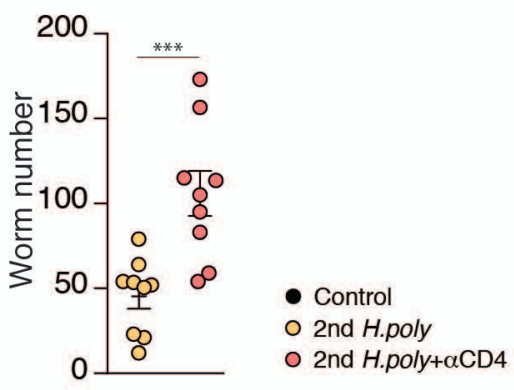

E

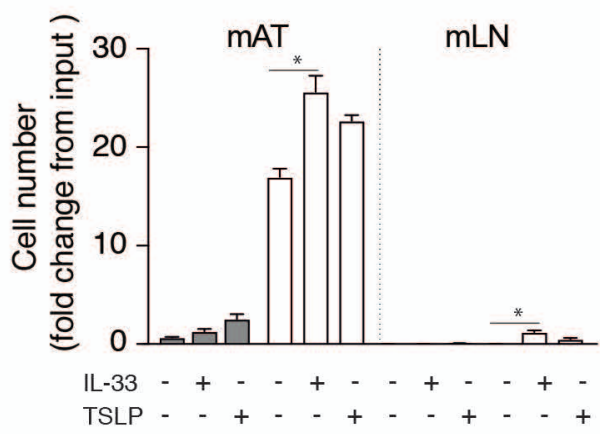

F

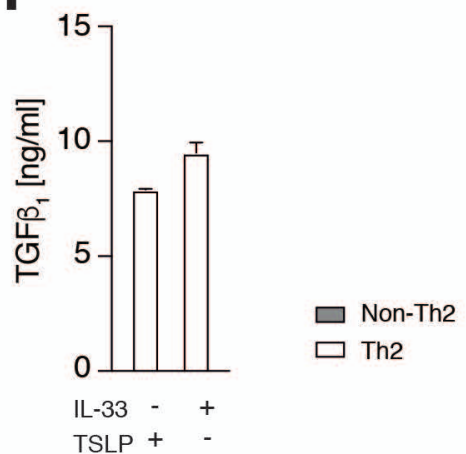


bioRxiv preprint doi: https://doi.org/10.1101/2022.02.24.481701; this version posted February $26,2022$. The copyright holder for this

preprint (which was not certified by peer review) is the author/funder, who has granted bioRxiv a license to display the preprint in perpetuity. It is made available under aCC-BY-NC-ND 4.0 International license.

\section{Fig. S7. Interdependence of $\mathrm{mAT}$ Th2 ${ }_{\mathrm{RM}}$ and stromal cells}

(A-C) Mice were subjected to secondary infection with $H$. polygyrus with experimental groups treated with anti-CD4 antibody as indicated (see Methods). Percentages (A) and numbers (B) of GATA3 ${ }^{+}$IL-33R ${ }^{+}$Th2 cells (gated on Foxp3- TCR $^{+} \mathrm{CD}^{4} 5^{+}$live cells in lymphocyte gate). (C) Worm counts from small intestine. (D) IL-5 levels from trans-well coculture of sorted mAT Th2 cells $\left(\mathrm{CD}^{+} \mathrm{TCR}^{+} \mathrm{IL}^{-\mathrm{eGFP}}{ }^{+}\right.$Foxp3RFP $)$with SC isolated from $H$. polygyrus infected mice or supernatants collected from SC culture from $H$. polygyrus infected mice (cMedium), as indicated. (E, F) Th2 cells $\left(\mathrm{CD} 4^{+} \mathrm{TCR} \beta^{+}\right.$IL4-eGFP ${ }^{+}$ Foxp3RFP-) and non-Th2 CD4 ${ }^{+}$T cells $\left(\mathrm{CD}^{+}{ }^{+} \mathrm{TCR}^{+}{ }^{+}\right.$IL4-eGFP- Foxp3RFP-) were sorted $^{-}$ from $\mathrm{mAT}$ and $\mathrm{mLN}$ of $H$. polygyrus infected mice and cultured for 3-6 days with addition of IL-33 [50ng/ml] or TSLP [50ng/ml] where indicated. (E) On day 3 cells were re-counted; numbers are presented as fold increases from the input cell numbers. (F) Levels of TGF $\beta_{1}$ in the supernatant from mAT Th2 cells after 6 days of culture.

Dot represents BR and error bars represent SEM from BR (A-B) or from TR (D-F). Data combined from 2 independent experiments $(C)$ or representative of 2 experiments (A, B, D, E), or from one experiment $(\mathrm{F})$. 
bioRxiv preprint doi: https://doi.org/10.1101/2022.02.24.481701; this version posted February 26, 2022. The copyright holder for this

preprint (which was not certified by peer review) is the author/funder, who has granted bioRxiv a license to display the preprint in

A

perpetuity It is made available under $\mathbf{B}$ CC-BY-NC-ND 4.0 International license.

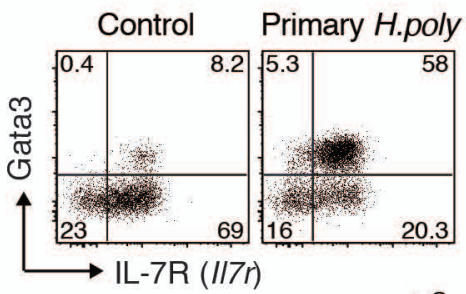

- Control

o Primary infection

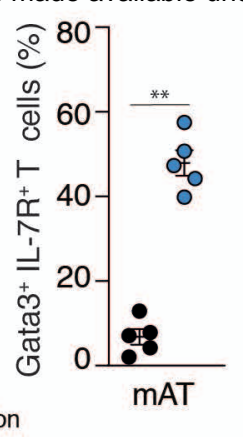

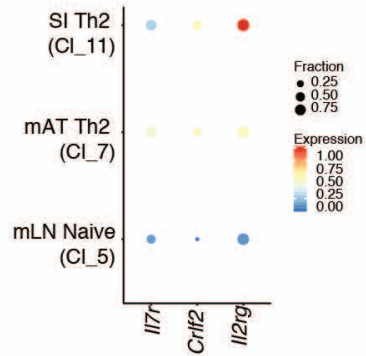

$\mathbf{F}$

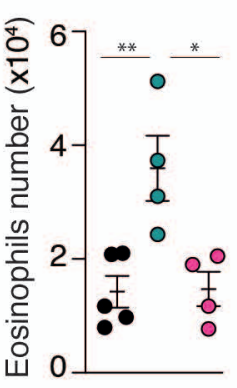

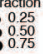
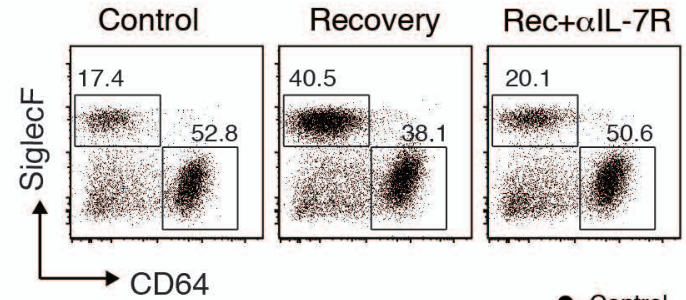

- Control

- Recovery

E

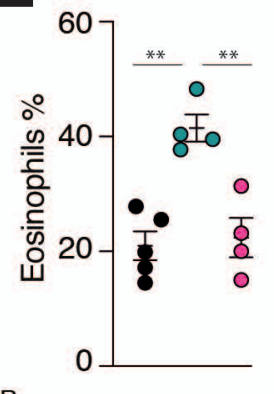

G

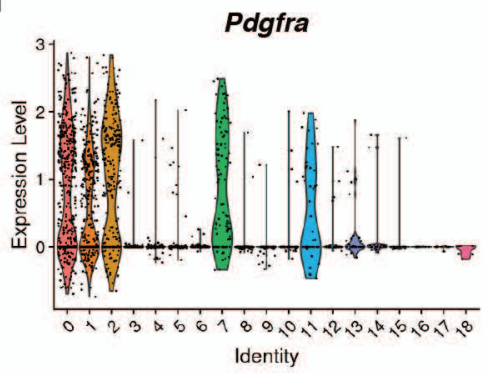

117

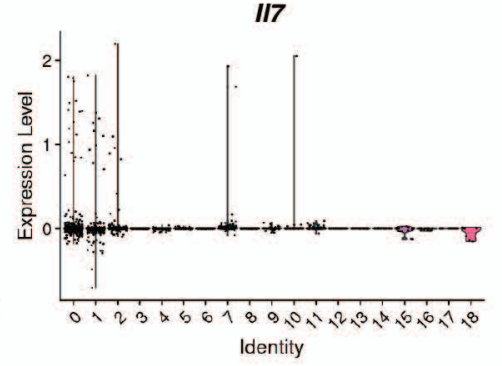


bioRxiv preprint doi: https://doi.org/10.1101/2022.02.24.481701; this version posted February $26,2022$. The copyright holder for this

preprint (which was not certified by peer review) is the author/funder, who has granted bioRxiv a license to display the preprint in perpetuity. It is made available under aCC-BY-NC-ND 4.0 International license.

\section{Fig. S8. mAT stromal cells support $\mathrm{Th} \mathbf{2}_{\mathrm{RM}}$ population}

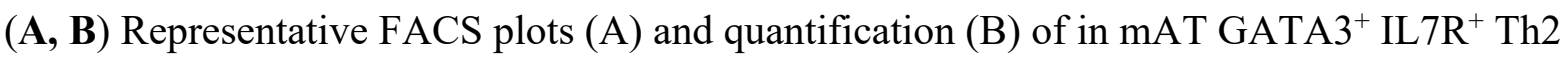
cells (gated on Foxp3-CD4+ $4^{+} \mathrm{TCR} \beta^{+} \mathrm{CD} 45^{+}$live cells in lymphocyte gate) during $H$. polygyrus infection. (C) scRNASeq dataset as shown in Fig.3: cluster-specific gene expression shown as dot plots where color represents the z-score of the mean expression across clusters and dot size represents the fraction of cells in the cluster expressing the selected gene. (D-F) TSLP signalling was blocked with anti-IL-7Ra antibody treatment during recovery after primary $H$. polygyrus infection (see Methods). Representative FACS plot (D) frequencies (E) and numbers (F) of SiglecF ${ }^{+} \mathrm{CD}^{-} 4^{-}$eosinophils (gated on $\mathrm{CD}^{+} 5^{+} \mathrm{CD} 11 \mathrm{~b}^{+}$cells) in $\mathrm{mAT}$. (G) scRNASeq dataset with cluster identification as shown in Fig.2A: violin plot representing expression levels of Pdgfra and $I l 7$ according to cell cluster.

Dot represents BR and error bars represent SEM from BR (B, E, F). Data from one experiment (A-G). 
bioRxiv preprint doi: https://doi.org/10.1101/2022.02.24.481701; this version posted February 26, 2022. The copyright holder for this

preprint (which was not certified by peer review) is the author/funder, who has granted bioRxiv a license to display the preprint in

A

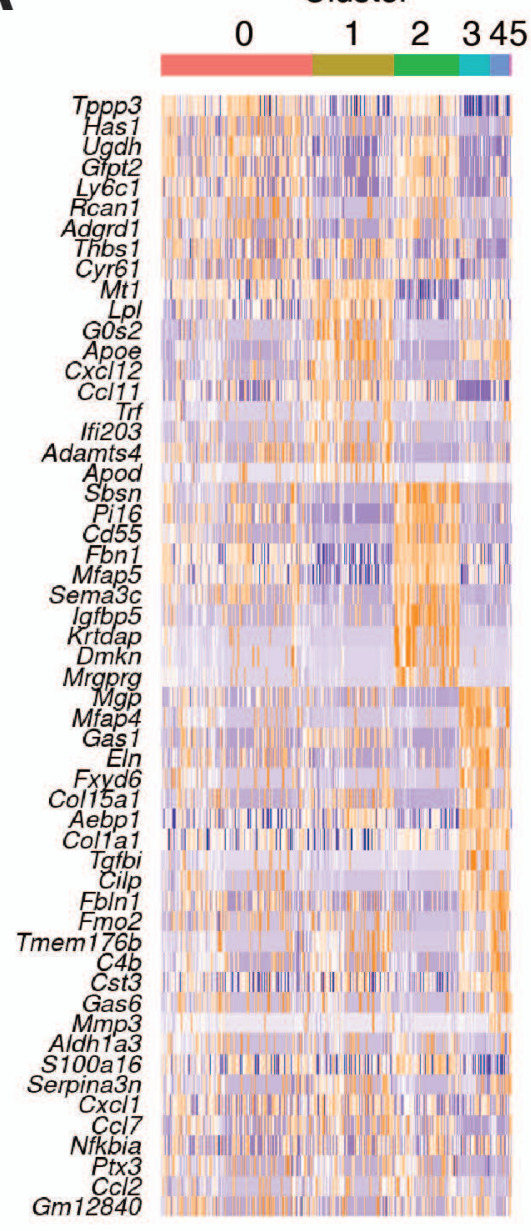

D

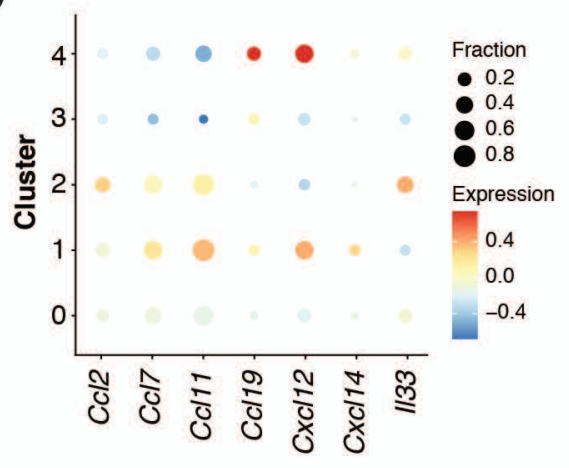

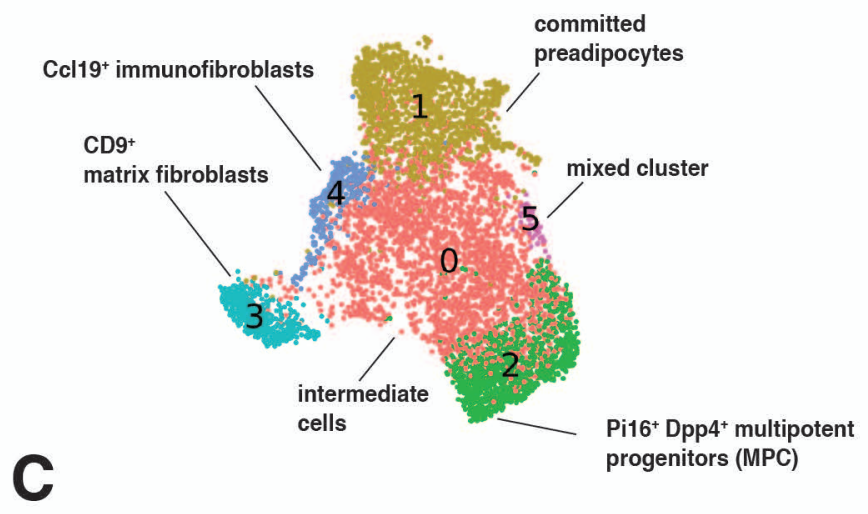
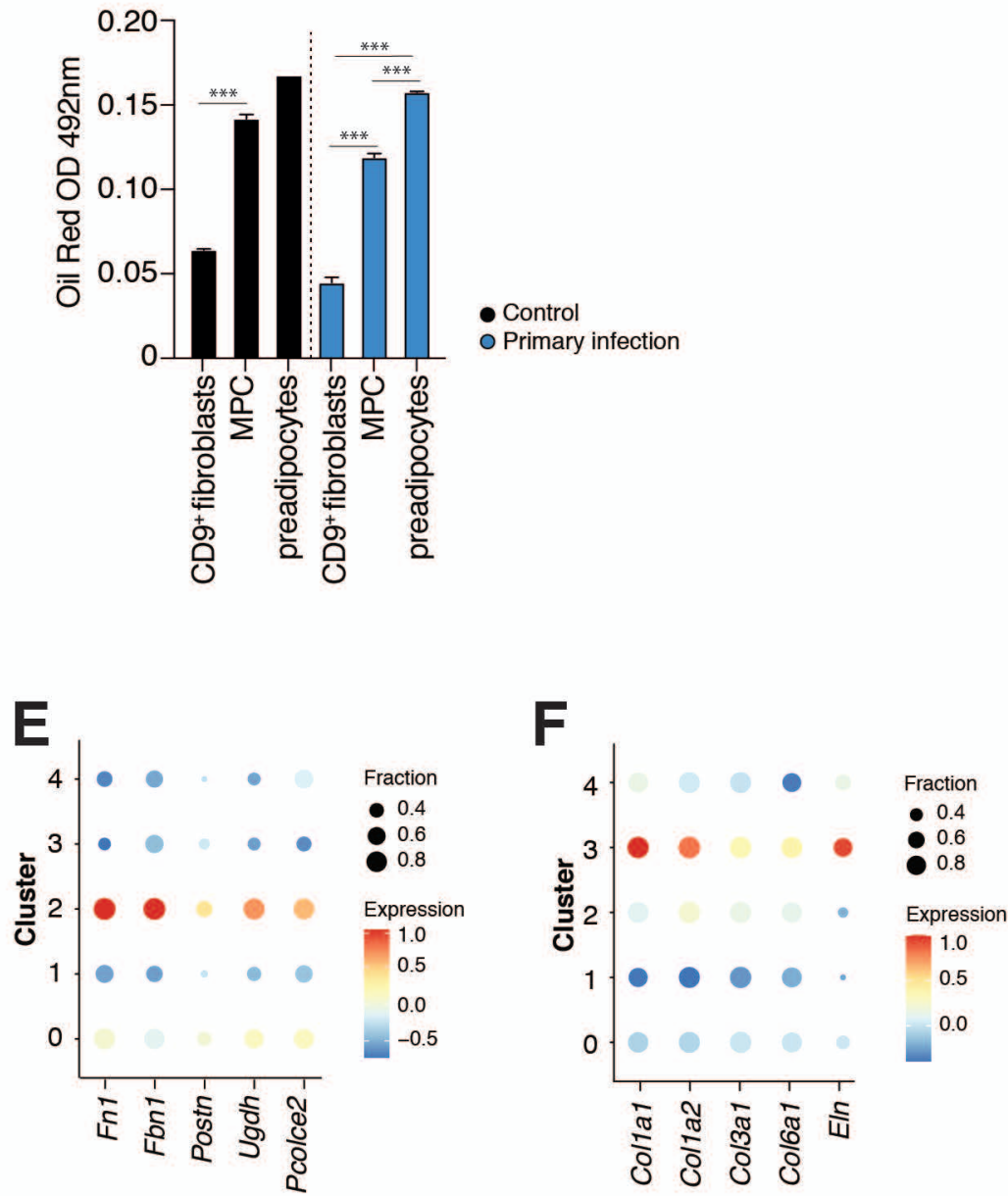
bioRxiv preprint doi: https://doi.org/10.1101/2022.02.24.481701; this version posted February $26,2022$. The copyright holder for this

preprint (which was not certified by peer review) is the author/funder, who has granted bioRxiv a license to display the preprint in perpetuity. It is made available under aCC-BY-NC-ND 4.0 International license.

Fig. S9. Characterization of mAT stromal cell populations in H. polygyrus infection

(A) Heatmap showing expression of top 10 differentially expressed genes in clusters as in panel B. (B) UMAP plot of 6059 mAT MSC from control (2457 cells), primary infected (2640 cells) and secondary infected mice (962 cells). Unsupervised clustering distinguished 6 cell clusters (C); plots are color-coded according to cell cluster. Identified cell population based on expression of following markers: committed preadipocytes (C1): Icam 1, Apoe, Lpl, Fabp4, Pparg; pluripotent progenitors (C2): Dpp4, Anxa3, Cd55, Pi16, Il33; CD9 ${ }^{+}$ profibrotic cells (3): Cd9, Wnt6, Eln, Mgp, Colla1, Col15a1, immunofibroblasts (C4): Cd9, Ccl19. (C) mAT SC were sorted into Ly6c- CD9 ${ }^{+}, \mathrm{Ly}^{-} \mathrm{c}^{+}$and $\mathrm{Ly}^{-} \mathrm{c}^{-} \mathrm{CD} 9^{-}$subpopulations and subjected to adipogenic differentiation (see Methods). Lipid content was quantified with Oil Red staining. (D-F) Sample-specific gene expression shown as dot plots. Color represents the $\log 2$ normalized expression of the mean expression across samples and dot size represents the fraction of cells in the cluster expressing the selected gene.

Error bars represent SEM from TR (C). Data from one experiment (A, B, D-F) or representative of two independent experiments (C). 

perpetuity. It is made available under aCC-BY-NC-ND 4.0 International license.

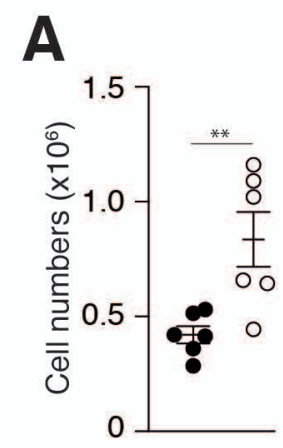

B

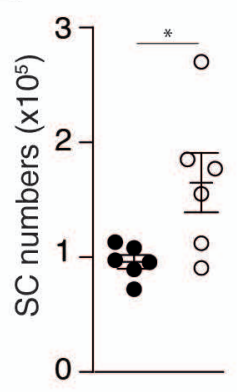

C

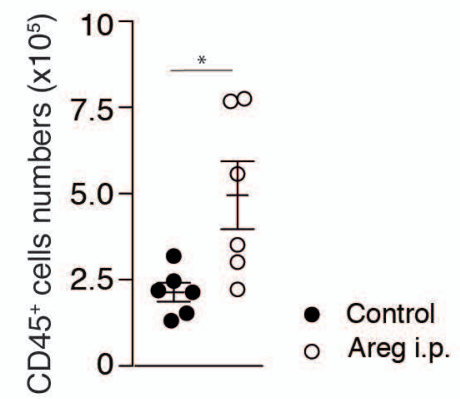

\section{S10_related to figure 6}


bioRxiv preprint doi: https://doi.org/10.1101/2022.02.24.481701; this version posted February $26,2022$. The copyright holder for this

preprint (which was not certified by peer review) is the author/funder, who has granted bioRxiv a license to display the preprint in perpetuity. It is made available under aCC-BY-NC-ND 4.0 International license.

Fig. S10. Areg supports mAT cellularity

(A-C) Mice were injected i.p. with Areg (3 injections, every third day) and mAT cells enumerated as indicated.

Dot represents BR and error bars represent SEM from BR (A-C). Data from one experiment. 


\section{Methods}

Mice and H. polygyrus infection model

We used C57BL/6J, (JAX:000664), Cd4-Cre (JAX: 022071), Pdgfra-Cre (JAX:013148), Il4eGFP Foxp3RFP Il10Bit (generated by crossing Il4 ${ }^{\mathrm{tm} 1 \mathrm{Lky}(47)}(47)$, Foxp $^{\mathrm{tm} 1 \mathrm{Flv}}(48)$ and $\operatorname{Tg}\left(I 110\right.$-Thyla) (49) mice, kindly provided by M. Wilson), Il4ra ${ }^{t m 2 F b b}$ (IL-4Rfl/fl) (50), kindly provided by F. Brombacher, and $E g f r^{t m 1 D w t}$ (EGFRfl/fl) (51) mice. All mice were maintained in specific-pathogen-free conditions in the animal facility of the Max Planck Institute for Immunobiology and Epigenetics (Freiburg, Germany), and all corresponding animal protocols were approved by the animal care committee of the Regierungspraesidium Freiburg. For H. polygyrus infection, mice were gavaged with 200 infectious L3 stage larvae in PBS. For primary infection, mice were left for 11-14 days before being sacrificed or treated with the anthelminthic pyrantel pamoate $(1 \mathrm{mg} / \mathrm{mouse})$. For secondary infection, mice were infected at 5 weeks post treatment, and sacrificed 11-14 days later. For $\mathrm{CD}^{+}{ }^{+} \mathrm{T}$ cell depletion, mice were infected and treated, and 5 weeks later injected with anti-CD4 monoclonal antibody (mAb, clone GK1.5, BioXCell, $500 \mu \mathrm{g}$ /mouse, i.p. per injection) one day before secondary infection, and then again at day 6 after infection. Mice were sacrificed on day 11 of secondary infection. For IL-7R $\alpha$ blockade, mice were infected and treated, and injected with anti-IL-7R $\alpha$ mAb (clone A7R34, BioXCell, $500 \mu \mathrm{g} /$ mouse, i.p. per injection) on days 3 and 9 post treatment, and sacrificed on day 12 post treatment. For treatment with FTY720 (Enzo, BML-SL233-0005), mice were infected and treated, and 5 weeks later injected with FTY720 every second day, starting from one day before secondary infection (6 injections in total, $10 \mu \mathrm{g} /$ mouse, i.p. per injection). Mice were sacrificed on day 11 of secondary infection. For Areg (R\&D System, 989-AR) treatment, naïve mice were injected 3 times with $10 \mu \mathrm{g} / \mathrm{mouse}$ Areg i.p. on day 0,3, and 6 and were sacrificed on day 9. In all experiments mice were age and sex matched. Both females and males were used. For the 
bioRxiv preprint doi: https://doi.org/10.1101/2022.02.24.481701; this version posted February $26,2022$. The copyright holder for this

preprint (which was not certified by peer review) is the author/funder, who has granted bioRxiv a license to display the preprint in perpetuity. It is made available under aCC-BY-NC-ND 4.0 International license.

magnetic resonance imaging (MRI), an EchoMRI 3-in-1 Body Composition Analyzer (EchoMRI) was used according to the manufacturer's instructions.

\section{H. polygyrus egg and adult worm counts}

Small intestines were removed, opened longitudinally, and placed into a mesh cloth on top of a $50 \mathrm{ml}$ tube filled with PBS for $3-4 \mathrm{~h}$ in a $37^{\circ} \mathrm{C}$ water batch. Parasites dropped through the mesh into the tube and were recovered for counting on a dissecting microscope. Parasite eggs in caecal contents collected from individual mice were collected and enumerated by floatation on sodium chloride and counted under a microscope.

\section{Isolation of cells from mAT and SI LP}

For isolation of cells from mAT, mice were euthanised and transcardially perfused with $10 \mathrm{ml}$ of ice-cold PBS. mAT was surgically separated from mLN, intestine and omentum, minced and digested in $3 \mathrm{ml}$ of low glucose DMEM containing $25 \mathrm{mM}$ HEPES, 1\% low fatty acid BSA, 2 mM L-glutamine (L-glut), $100 \mathrm{U} / \mathrm{ml}$ Penicillin/Streptomycin (P/S), with the addition of Liberase TL ( $0.2 \mathrm{mg} / \mathrm{ml}$, Roche) and DNase I ( $0.25 \mathrm{mg} / \mathrm{ml}$, Roche) for $30-40 \mathrm{~min}$ at $37^{\circ} \mathrm{C}$ on a rotator. After digestion, $2 \mathrm{ml}$ DMEM containing $2 \mathrm{mM}$ EDTA was added and the suspension was filtered through $70 \mu \mathrm{m}$ strainers. Cells in SVF were separated from the adipocyte layer by centrifugation. For isolation of cells from SI LP, SI were opened longitudinally, cleaned with PBS, cut into $2 \mathrm{~cm}$ pieces and placed in RPMI containing 3\% FBS, $25 \mathrm{mM}$ HEPES, $2 \mathrm{mM}$ L-glut, $100 \mathrm{U} / \mathrm{ml} \mathrm{P} / \mathrm{S}, 1 \mathrm{mM}$ DTT and agitated for $25 \mathrm{~min}$, after which samples were washed 3-4 times with RPMI containing 2 mM EDTA. Intestines were digested in RPMI containing 25 mM HEPES, 2 mM L-glut, $100 \mathrm{U} / \mathrm{ml}$ P/S, Liberase TL (0.1 $\mathrm{mg} / \mathrm{ml}$, Roche), DNase I (50 $\mathrm{g} / \mathrm{ml}$, Roche) for $30 \mathrm{~min}$ at $37^{\circ} \mathrm{C}$ with agitation. Cell suspensions were filtered through $70 \mu \mathrm{m}$ strainers, centrifuged and resuspended in $3 \mathrm{ml}$ P30 solution (30\% Percoll, GE, Amersham, UK). Overlaying $3 \mathrm{ml} \mathrm{P75}$ with $4 \mathrm{ml} \mathrm{P40} \mathrm{and} \mathrm{then} 3$ 
ml P30 containing SI LP leukocytes created a three-layered discontinuous gradient. Gradients were centrifuged $\left(1800 \mathrm{rpm} / 680 \mathrm{~g}, 20^{\circ} \mathrm{C}, 20 \mathrm{~min}\right)$ and enriched leukocytes isolated from the P40/P75 interface.

$\underline{\text { SC cultures }}$

SC were isolated from SVF using the Adipose Tissue Progenitor Isolation Kit (Miltenyi Biotec, \#130-106-639). Isolated SC were plated at 2-4x10 cells/well in 48 well plates and cultured overnight at $37^{\circ} \mathrm{C}, 5 \% \mathrm{CO}_{2}$ in cRPMI medium (RPMI containing $10 \%$ FBS, 25 mM HEPES, 2 mM L-glut, $100 \mathrm{U} / \mathrm{ml}$ P/S, cRPMI). Supernatants were then collected and cytokines or pColl measured by ELISA. In experiments where effects of Areg on SC biology were assessed over longer culture periods, adipogenic factors were added to mimic adipose tissue conditions. SC from mAT of naïve mice were seeded at near confluency and cultured in complete DMEM/F12 medium (DMEM/F12, 10\% FBS, 1 mM sodium pyruvate, $2 \mathrm{mM}$ L-glut, $100 \mathrm{U} / \mathrm{ml} \mathrm{P} / \mathrm{S}$ ) supplemented with dexamethasone (Sigma, \#D-1756, $0.5 \mu \mathrm{M}$ ), 3-isobutyl-1-methylxanine (IBMX, Sigma, \#I-5879, 0.5 mM), insulin (Sigma, \#I-5523, 1.7 $\mu \mathrm{M}$ ) and Rosiglitazone (Sigma, \#R2408, $1 \mu \mathrm{M}$ ). Medium was changed every second day and on day 4 was replaced with adipogenic medium containing only insulin. Where indicated, cells were cultured with Areg (R\&D Systems, \#989-AR-100, 10 or $100 \mathrm{ng} / \mathrm{ml}$ ) or heptelidic acid (Adipogen, \#AG-CV2-0118-M00, $10 \mu \mathrm{M}$ ).

In experiments where the adipogenic potential of mAT SC subpopulations was assessed, cells were sorted according to CD9 and Ly6c expression and plated at equivalent cell numbers in complete DMEM/F12 medium for $24 \mathrm{~h}$, after which the medium was supplemented with minimal adipogenic medium: $1 \mu \mathrm{M}$ dexamethasone (Sigma, \#D-1756), 3isobutyl-1-methylxanine (IBMX, Sigma, \#I-5879, 0.5 mM), insulin (Sigma, \#I-5523, $20 \mathrm{nM}$ ) and Rosiglitazone (Sigma, \#R2408, 1 $\mu \mathrm{M}$ ). Medium was changed every second day of the 
culture and from day 4 adipogenic medium was supplemented only with $20 \mathrm{nM}$ insulin. Lipid droplets were visualized on day 7 of the culture using Oil Red solution (Sigma, 01391): briefly, cells were fixed with $10 \% \mathrm{NBF}$ (Sigma) for 30 min at RT, washed with $\mathrm{H}_{2} \mathrm{O}$ and incubated with $60 \%$ Isopropanol/ $\mathrm{H}_{2} \mathrm{O}$ for $5 \mathrm{~min}$, followed by staining with $60 \%$ Oil Red/ $\mathrm{H}_{2} \mathrm{O}$ solution for 20 min. Cell were washed with $\mathrm{H}_{2} \mathrm{O}$ before microscopy. For semiquantification, cells were additionally washed with $60 \%$ Isopropanol/ $\mathrm{H}_{2} \mathrm{O}$, after which Oil Red was released from the cells by incubation with 100\% Isopropanol for $5 \mathrm{~min}$. Absorbance was read at $492 \mathrm{~nm}$.

\section{Isolation and culture of $\mathrm{mAT}$ and $\mathrm{mLN} \mathrm{T}$ cells}

Triple reporter (Il4 ${ }^{\mathrm{tm} 1 \mathrm{Lky}}$ Foxp $3^{\mathrm{tm} 1 \mathrm{Flv}} \mathrm{Tg}(\mathrm{Il1} 10$-Thy1a) mice were infected with H. polygyrus as described above and Th2 cells (TCR $\beta^{+} \mathrm{CD}^{+} \mathrm{IL}^{-}-\mathrm{eGFP}^{+}$Foxp3-RFP-) and non-Th2 effector T cells $\left(\mathrm{CD} 45^{+} \mathrm{TCR}^{+} \mathrm{CD}^{+}{ }^{+}\right.$IL4-eGFP- Foxp3-RFP-) were FACS-sorted, plated at $1-2 \times 10^{4}$ cells/well in 96 U-bottom plate and cultured for $3-6$ days in cRPMI medium in the presence of IL-33 (R\&D Systems, \#3626, 50 ng/ml) or TSLP (R\&D Systems, \#555-TS, 50ng/ml) where indicated. Cells were then enumerated and supernatants were collected for cytokine measurements. In co-culture experiments, SC from control or H. polygyrus infected mice were purified as described above and plated at $5 \times 10^{4} /$ well in flat bottom 96 -well plates, or at $1.7 \times 10^{5} /$ well in the lower chamber of a 96 trans-well plate (Corning, 3381, $0.4 \mu \mathrm{m}$ polycarbonate membrane). One day later, sorted T cells were added to the upper chamber (1$2 \times 10^{4}$ cells per well) and cultured for 3-4 days, after which cells were enumerated and supernatants collected for cytokine measurement.

\section{Histological staining}


mAT and mLN tissue sections were fixed in buffered $10 \%$ formalin and paraffinembedded. Sections were then cut and stained with hematoxylin and eosin. Images were acquired using a Zeiss Axio Imager Apotome microscope.

Immunofluorescence staining and microscopy

mAT samples were fixed for 60 min on ice in 10\% NBF (Sigma), permeabilized in 1\% Triton X-100 in PBS (Sigma) for $30 \mathrm{~min}$ at room temperature (RT) and blocked for 30 min at RT with $2.5 \%$ BSA, $0.5 \%$ Triton X-100 in PBS. mAT samples were incubated with primary antibodies, anti-CD3 (Abcam, ab5690, rabbit polyclonal), anti-Perilipin-1 (Abcam, ab61682, goat polyclonal), anti-PDGFRa (R\&D System AF1062, goat polyclonal) and GATA3-e660 (Invitrogen, mAb clone TWAJ) in 0.5\% BSA, 0.5\% Triton X-100 in PBS for 60 min at RT followed by three washes with $0.5 \%$ BSA, 0.5\% Triton X-100 in PBS. After washing, samples were incubated with secondary antibodies conjugated with Alexa Fluor 488 and/or Alexa Fluor 568 (Thermofisher) in $0.5 \%$ BSA, 0.5\% Triton X-100 in PBS for 60 min. All antibodies were used at 1:100 dilution. Nuclei were stained with Hoechst 33342 (Thermofisher, $2 \mu \mathrm{g} / \mathrm{ml}$ ) in $0.5 \%$ BSA, $0.5 \%$ Triton X-100 in PBS for $30 \mathrm{~min}$. Samples were mounted with ProLong ${ }^{\circledR}$ Diamond Antifade Mountant (Thermofisher). Confocal images were acquired using a Zeiss spinning disk confocal microscope equipped with a Photometrics Prime BSI camera and Apochromat objectives.

\section{Flow Cytometry}

For analysis of intracellular cytokine production cells were re-stimulated for 4 hours at $37^{\circ} \mathrm{C}$ in RPMI media supplemented with $10 \% \mathrm{FCS}, 2 \mathrm{mM} \mathrm{L}$-glut, $100 \mathrm{U} / \mathrm{ml} \mathrm{P/S}$ with 0.1 $\mu \mathrm{g} / \mathrm{ml}$ Phorbol 12-myristate 13- acetate (PMA), $1 \mu \mathrm{g} / \mathrm{ml}$ Ionomycin and $10 \mu \mathrm{g} / \mathrm{ml}$ Brefeldin A. Cells were surface stained with mAbs diluted in PBS/0.1\% BSA and Fc-block (Biolegend) for 30 min on ice. Fixable Viability Dye (eBioscience) was added to allow the exclusion of 
dead cells from the analysis. The following fluorochrome-conjugated antibodies from Biolegend or BD Bioscience were used: CD4 (clone RM4-5), CD9 (clone MZ3), CD11b (clone M1/70), CD11c (clone N418), CD24 (clone M1/69), CD29 (clone HMb1-1), CD31 (clone 390), CD45 (clone 30-F11), PDGFRa (clone APA5), Ly6A (E13-161.7), Ly6C (clone HK1.4), Ly6G (clone 1A8), CD44 (clone IM7), CD49d (clone R1-2), CD62L (clone MEL14), CD64 (clone X54-5/7.1), CD69 (clone H1.2F3), F4/80 (clone BM8), IL-7R (clone A7R34), SiglecF (clone E50-2440), TCR $\beta$ (clone H57-597), Thy1 (clone 53-2.2). Additionally, biotinylated antibodies were used for the staining ST2 (IL-33R) (Mdb, clone DJ8) and TSLPR (Biolegend, 22H9). For intracellular staining, cells were fixed and permeabilized using the Foxp3/transcription factor staining kit (eBioscience), and incubated with the following fluorochrome-conjugated mAb: GATA3 (clone TWAJ), Foxp3 (clone FJK-16s), IL-5 (clone TRFK5), IFN $\gamma$ (XMG1.2), TGFB1-LAP (clone TW7-16B4), Ki67 (clone SolA15). Areg was detected with a biotinylated mAb (R\&D Systems, BAF989). To identify ILC, a cocktail of biotinylated mAb against the following surface markers was used to allow gating on linage negative cells: NK1.1, CD19, CD5, F4/80, CD11c, Ter119, Cd3e, CD11b, LysG1, TCR $\gamma \delta$. Binding of biotinylated antibodies was detected using fluorochromeconjugated streptavidin (Biolegend). Flow cytometry analyses were performed on a Fortessa flow cytometer (BD) and data were analyzed with FlowJo 9.9.4 software (BD).

\section{Cytokine and pColl measurements}

Concentrations of Areg, IL-33, TSLP and pColl in cell culture supernatants were determined using ELISA kits (R\&D System for Areg, IL-33 and TSLP, and Abcam for pCol1). Unless stated otherwise, data were normalized to $1 \times 10^{6} / \mathrm{ml}$ cells for MSC supernatants and $1 \times 10^{5} / \mathrm{ml}$ for $\mathrm{T}$ cell supernatants. For measuring IL-2, IL-4, IL-5, IL-6, IL13 and TGF $\beta$ we used the LEGENDplex mouse Th Cytokine panel (Biolegend, \#741044) and the Mouse/Rat Active/Total TGF $\beta$ assay (Biolegend, \#740490). 


\section{Metabolic Profiling}

Oxygen consumption rates (OCR) and extracellular acidification rates (ECAR) were measured in XF media (non-buffered RPMI 1640 containing 25 mM glucose, 2mM L-glut, and $1 \mathrm{mM}$ sodium pyruvate) under basal conditions and in response to $1 \mu \mathrm{M}$ oligomycin, 1.5 $\mu \mathrm{M}$ fluoro-carbonyl cyanide phenylhydrazone $(\mathrm{FCCP})$ and $100 \mathrm{nM}$ rotenone $+1 \mu \mathrm{M}$ antimycin A using a 96 well XF or XFe Extracellular Flux Analyzer (EFA) (Seahorse Bioscience). $2 \times 10^{5}$ freshly isolated mAT MSC were spun onto poly-D-lysine-coated seahorse 96 well plates and preincubated at $37^{\circ} \mathrm{C}$ for a minimum of $45 \mathrm{~min}$ in the absence of $\mathrm{CO}_{2}$. For the measurement of OCR and ECAR in MSC that were undergoing adipogenic differentiation, cells were culture in the seahorse 96 well plates in the presence of adipogenesis inducing factors as stated above for 3 days, after which medium was changed to XF media before the measurement. Glucose, glutamine and lactate concentrations MSC culture supernatants were measured using a Cedex Bio Analyzer (Roche).

\section{$\underline{\text { RNA sequencing }}$}

RNA isolations were done using Ambion's RNAqueous Micro Kit (Cat 1931) according to manufacturer's instructions and quantified using Qubit 2.0 (Thermo Fisher Scientific). Libraries were prepared using the TruSeq stranded mRNA kit (Illumina) and sequenced in a HISeq 3000 (Illumina) by the Deep-Sequencing Facility at the Max Planck Institute for Immunobiology and Epigenetics. Sequenced libraries were processed in an inhouse developed RNA sequencing pipeline (52) that employs deepTools for quality control (53), cutadapt for trimming (DOI:10.14806/ej.17.1.200), STAR for mapping (54) and featureCounts to quantify mapped reads (55). Raw counts of mapped reads were processed in R (Lucent Techonologies) with DESeq2 (50) to determine differentially expressed genes and generate normalized read counts to visualize as heatmaps using Morpheus (Broad Institute). 
Pathway enrichment analysis was performed using in house application 'Gene2Functions' (https://github.com/maxplanck-ie/Genes2Functions).

$\underline{\text { Single cell }} \underline{\text { RNA }} \underline{\text { sequencing: }} \underline{\mathrm{mAT}} \underline{\mathrm{SVF}} \underline{\text { single cell sequencing }}$

Single cell RNA sequencing of sorted mAT SVF cells was performed using a 10X Genomics Chromium Controller. Single cells were processed with GemCode Single Cell Platform using GemCode Gel Beads, Chip and Library Kits (v2) following the manufacturer's protocol. Libraries were sequenced on HiSeq 3000 (Illumina). Samples were demultiplexed and aligned using Cell Ranger 2.2 (10X genomics) to genome build GRCm38 to obtain a raw read count matrix of barcodes corresponding to cells and features corresponding to detected genes. Read count matrices were processed, analyzed and visualized in R using Seurat v.3 (57) and Uniform Manifold Approximation and Projection (UMAP) (McInnes, L, Healy, J, UMAP: Uniform Manifold Approximation and Projection for Dimension Reduction, ArXiv e-prints $1802.03426,2018$ ) as a dimensionality reduction approach. Only cells with high quality transcriptomes (low \% of mitochondrial RNA content and more than 200 detected genes) were used for data normalization and integration. Datasets were normalizes using a regularized negative binomial regression, and harmonized by identifying mutual nearest neighbors across datasets and applying canonical correlation analysis. Differentially expressed genes within each cluster and across conditions were determined with Seurat as those with a greater than 1.2-fold change and an adjusted $p$ value of less than 0.05 . Pseudotime was estimated using Monocle (26) setting pluripotent progenitor pre-adipocytes as the origin differentiation trajectories. Potential cell-to-cell interactions between selected populations were detected using CellPhone $(27)$, where significant ( $p$ value $<0.05$ ) means of the average expression levels of the interacting partner in the target cell types are presented as a heatmap. For the pathway enrichment analysis for the MSC clusters genes differentially expressed in each cluster compared to all other clusters where adjusted $\mathrm{p}$ value was lower 
than 0.01 and expression greater than $0.25 \log \mathrm{FC}$ were used to calculate pathway enrichment against GO terms in the biological process category. GO pathways where the sum of $p$ values for each cluster was greater than 5.3 were then selected.

\section{Single cell RNA sequencing: $\mathrm{CD}^{+} \mathrm{T}$ cell single cell sequencing}

Live $\mathrm{CD} 45^{+} \mathrm{CD}^{+} \mathrm{TCR} \beta^{+} \mathrm{T}$ cells from $\mathrm{mLN}$ and $\mathrm{mAT}$ of control ( 2 mice per condition), primary infected (one mouse per condition) and secondary infected (one mouse per condition) and from SI LP of control and primary infected mice (2 mice per condition) were FACS sorted into 384-well plates containing lysis buffer (Herman et al., 2018). Plates were centrifuged for $5 \mathrm{~min}$ at $2200 \mathrm{~g}$ at $4^{\circ} \mathrm{C}$, snap-frozen in liquid nitrogen and stored at $-80^{\circ} \mathrm{C}$ until processed. Single cell RNA sequencing was performed using the CEL-Seq2 method (58) with modifications as described (59). $\mathrm{CD}^{+} \mathrm{T}$ cells were sequenced on a HiSeq 2500 or HiSeq 3000 sequencing system (Illumina paired-end multiplexing run, high output mode) at a depth of $\sim 77,000-\sim 518,000$ reads per cell.

Paired end reads were aligned to the transcriptome using bwa (version 0.6.2-r126) with default parameters $(60)$. The transcriptome contained all gene models based on the mouse ENCODE VM9 release downloaded from the UCSC genome browser comprising 57,207 isoforms with 57,114 isoforms mapping to fully annotated chromosomes (1 to 19, X, Y, M). All isoforms of the same gene were merged to a single gene locus. Furthermore, gene loci overlapped by $>75 \%$ were merged to larger gene groups. This procedure resulted in 34,111 gene groups. The loci for Nmurl was extended at the 3' end to position 86,384,000 on the chromosome 1 (39). The right mate of each read pair was mapped to the ensemble of all gene loci in sense direction. Reads mapping to multiple loci were discarded. The left read contained the barcode information: The first six bases corresponded to the unique molecular identifier (UMI), followed by six bases representing the cell specific barcode. The remainder of the left read contained a polyT stretch. The left read was not used for quantification. For 
each cell barcode, the number of UMIs per transcript was counted and aggregated across all transcripts derived from the same gene locus. Based on binomial statistics, the number of observed UMIs was converted into transcript counts (61). The dataset was analyzed using RaceID3 (v0.1.3 and v0.1.6). Rescaling to 2,000 transcripts per cells was used for data normalization. Prior to filtering and normalization, mitochondrial genes were excluded and cells expressing $>2 \%$ of Kcnqlot 1 transcripts, identified as a marker of low-quality cells (62) were removed from analysis. This resulted in total $3431 \mathrm{CD}^{+} \mathrm{T}$ cells with high quality transcriptomes and 26262 quantified genes across these cells. RaceID3 was run with the following parameters: mintotal $=2,000$, minexpr $=3$, outminc $=3$, FSelect $=$ TRUE, probthr $=10^{-}$ ${ }^{3}$, ccor $=0.65$. In addition, we used imputing implemented in RaceID3 with knn=10. To remove batch effects and technical variability, we initialized the following sets of genes as CGenes: ensemble of all Gm, RP, Hsp and A4300 genes, Malat1, Xist, Mid1 and Kcnq1ot1. After initial clustering, cells within clusters with macrophage and plasma cell signature were removed and RaceID3 was rerun with the same parameters described above and Lars2 was included in CGenes. In the final clustering step, VarID (18) was used with the distance matrix derived from RaceID3 clustering and the following pruning parameters: knn=10, alpha=1, FSelect=FALSE and the default density clustering parameters.

Due to recognized technical difficulties related to excessive mucus production, we were unable to isolate live SI cells from mice with secondary infection (63).

For the SVF scRNASeq analysis male mice were used, for the $\mathrm{CD}^{+} \mathrm{T}$ cell scRNASeq female mice were used.

\section{Fraction dot plot for clusters:}

Cluster-specific gene expression where color represents the $\mathrm{Z}$ score of the mean expression or $\log 2$ expression across clusters and dot size represents the fraction of cells in the cluster expressing the selected gene. For expression color code, $\log 2$ mean expression above for 4 or 
bioRxiv preprint doi: https://doi.org/10.1101/2022.02.24.481701; this version posted February $26,2022$. The copyright holder for this

preprint (which was not certified by peer review) is the author/funder, who has granted bioRxiv a license to display the preprint in perpetuity. It is made available under aCC-BY-NC-ND 4.0 International license.

below -4 are replaced by 4 and -4 , respectively. $Z$ scores above 1 and -1 are replaced by 1 and -1 , respectively.

\section{Quantification and Statistical Analysis}

With the exception of scRNASeq and RNASeq dataset, statistical analysis for the remaining results were performed using Prism 7 software (GraphPad) and results are represented as Mean \pm SEM. Comparisons for two groups were calculated using nonparametric Mann-Whitney test or unpaired two-tailed Student's t tests. Comparisons of more than two groups were calculated using one-way ordinary unpaired ANOVA with Bonferroni's multiple comparison tests. Designation of $\mathrm{p}$-values were as follows: * $\leq 0.05$; * $\leq 0.01 ; * * * \leq 0.001$

For in vivo experiments, sample size was determined by power analysis and calculated required sample sizes were applied whenever possible. Selection of sample size for in vitro experiments was based on previous experience. 


\section{References}

1. A. B. Molofsky et al., Innate lymphoid type 2 cells sustain visceral adipose tissue eosinophils and alternatively activated macrophages. J. Exp. Med. 210, 535-549 (2013).

2. J. R. Brestoff et al., Group 2 innate lymphoid cells promote beiging of white adipose tissue and limit obesity. Nature 519, 242-246 (2015).

3. M. W. Lee et al., Activated Type 2 Innate Lymphoid Cells Regulate Beige Fat Biogenesis. Cell 160, 74-87 (2015).

4. D. Wu et al., Eosinophils sustain adipose alternatively activated macrophages associated with glucose homeostasis. Science 332, 243-247 (2011).

5. D. Cipolletta et al., PPAR-gamma is a major driver of the accumulation and phenotype of adipose tissue Treg cells. Nature 486, 549-553 (2012).

6. A. Vasanthakumar et al., The transcriptional regulators IRF4, BATF and IL-33 orchestrate development and maintenance of adipose tissue-resident regulatory $\mathrm{T}$ cells. Nat. Immunol. 16, 276-285 (2015).

7. T. Mahlakoiv et al., Stromal cells maintain immune cell homeostasis in adipose tissue via production of interleukin-33. Sci Immunol 4, (2019).

8. R. G. Spallanzani et al., Distinct immunocyte-promoting and adipocyte-generating stromal components coordinate adipose tissue immune and metabolic tenors. Sci Immunol 4, (2019).

9. B. M. J. Rana et al., A stromal cell niche sustains ILC2-mediated type-2 conditioning in adipose tissue. J. Exp. Med. 216, 1999-2009 (2019).

10. D. Kolodin et al., Antigen- and cytokine-driven accumulation of regulatory T cells in visceral adipose tissue of lean mice. Cell Metab. 21, 543-557 (2015).

11. S. Obi et al., IL-33 is essential to prevent high-fat diet-induced obesity in mice infected with an intestinal helminth. Parasite Immunol. 42, e12700 (2020).

12. C. W. Su et al., Helminth infection protects against high fat diet-induced obesity via induction of alternatively activated macrophages. Sci. Rep. 8, 4607 (2018).

13. S. J. Han et al., White Adipose Tissue Is a Reservoir for Memory T Cells and Promotes Protective Memory Responses to Infection. Immunity 47, 1154-1168 e1156 (2017).

14. D. Merrick et al., Identification of a mesenchymal progenitor cell hierarchy in adipose tissue. Science 364, (2019).

15. C. Benezech et al., Inflammation-induced formation of fat-associated lymphoid clusters. Nat. Immunol. 16, 819-828 (2015).

16. K. Moro et al., Innate production of $\mathrm{T}(\mathrm{H}) 2$ cytokines by adipose tissue-associated cKit(+)Sca-1(+) lymphoid cells. Nature 463, 540-544 (2010).

17. S. J. Van Dyken et al., A tissue checkpoint regulates type 2 immunity. Nat. Immunol. 17, 1381-1387 (2016).

18. D. Grun, Revealing dynamics of gene expression variability in cell state space. Nat Methods 17, 45-49 (2020).

19. S. Steinfelder, S. Rausch, D. Michael, A. A. Kuhl, S. Hartmann, Intestinal helminth infection induces highly functional resident memory $\mathrm{CD} 4(+) \mathrm{T}$ cells in mice. Eur. $J$. Immunol. 47, 353-363 (2017).

20. R. R. Ricardo-Gonzalez et al., Tissue signals imprint ILC2 identity with anticipatory function. Nat. Immunol. 19, 1093-1099 (2018).

21. J. Corren, S. F. Ziegler, TSLP: from allergy to cancer. Nat. Immunol. 20, 1603-1609 (2019).

22. P. C. Schwalie et al., A stromal cell population that inhibits adipogenesis in mammalian fat depots. Nature 559, 103-108 (2018). 
23. C. Hepler et al., Identification of functionally distinct fibro-inflammatory and adipogenic stromal subpopulations in visceral adipose tissue of adult mice. Elife 7, (2018).

24. G. Marcelin et al., A PDGFRalpha-Mediated Switch toward CD9(high) Adipocyte Progenitors Controls Obesity-Induced Adipose Tissue Fibrosis. Cell Metab. 25, 673685 (2017).

25. C. Perez-Shibayama et al., Fibroblastic reticular cells initiate immune responses in visceral adipose tissues and secure peritoneal immunity. Sci Immunol 3, (2018).

26. C. Trapnell et al., The dynamics and regulators of cell fate decisions are revealed by pseudotemporal ordering of single cells. Nat. Biotechnol. 32, 381-386 (2014).

27. M. Efremova, M. Vento-Tormo, S. A. Teichmann, R. Vento-Tormo, CellPhoneDB: inferring cell-cell communication from combined expression of multi-subunit ligandreceptor complexes. Nat. Protoc. 15, 1484-1506 (2020).

28. G. J. van der Windt et al., Mitochondrial respiratory capacity is a critical regulator of CD8+ T cell memory development. Immunity 36, 68-78 (2012).

29. M. B. Buechler et al., Cross-tissue organization of the fibroblast lineage. Nature, (2021).

30. J. Ordovas-Montanes et al., Allergic inflammatory memory in human respiratory epithelial progenitor cells. Nature 560, 649-654 (2018).

31. B. A. Shook et al., Myofibroblast proliferation and heterogeneity are supported by macrophages during skin repair. Science 362, (2018).

32. Z. Zhang et al., Dermal adipose tissue has high plasticity and undergoes reversible dedifferentiation in mice. J. Clin. Invest. 129, 5327-5342 (2019).

33. C. W. Y. Ha et al., Translocation of Viable Gut Microbiota to Mesenteric Adipose Drives Formation of Creeping Fat in Humans. Cell 183, 666-683 e617 (2020).

34. H. Lv et al., Mechanism of regulation of stem cell differentiation by matrix stiffness. Stem Cell. Res. Ther. 6, 103 (2015).

35. R. L. Gieseck, 3rd, M. S. Wilson, T. A. Wynn, Type 2 immunity in tissue repair and fibrosis. Nat. Rev. Immunol. 18, 62-76 (2018).

36. B. D. Hondowicz et al., Interleukin-2-Dependent Allergen-Specific Tissue-Resident Memory Cells Drive Asthma. Immunity 44, 155-166 (2016).

37. C. S. N. Klose et al., The neuropeptide neuromedin U stimulates innate lymphoid cells and type 2 inflammation. Nature 549, 282-286 (2017).

38. V. Cardoso et al., Neuronal regulation of type 2 innate lymphoid cells via neuromedin U. Nature 549, 277-281 (2017).

39. A. Wallrapp et al., The neuropeptide NMU amplifies ILC2-driven allergic lung inflammation. Nature 549, 351-356 (2017).

40. D.-H. Kim, S. J. Van Dyken, ILC2s in High Definition: Decoding the Logic of Tissue-Based Immunity. Trends Immunol. 41, 7-16 (2020).

41. M. Peine, R. M. Marek, M. Lohning, IL-33 in T Cell Differentiation, Function, and Immune Homeostasis. Trends Immunol. 37, 321-333 (2016).

42. D. M. Zaiss, W. C. Gause, L. C. Osborne, D. Artis, Emerging functions of amphiregulin in orchestrating immunity, inflammation, and tissue repair. Immunity 42, 216-226 (2015).

43. C. M. Minutti et al., A Macrophage-Pericyte Axis Directs Tissue Restoration via Amphiregulin-Induced Transforming Growth Factor Beta Activation. Immunity 50, 645-654 e646 (2019).

44. L. J. Zhang et al., Innate immunity. Dermal adipocytes protect against invasive Staphylococcus aureus skin infection. Science 347, 67-71 (2015).

45. B. O. Zhou et al., Bone marrow adipocytes promote the regeneration of stem cells and haematopoiesis by secreting SCF. Nat. Cell Biol. 19, 891-903 (2017). 
46. J. E. Heredia et al., Type 2 innate signals stimulate fibro/adipogenic progenitors to facilitate muscle regeneration. Cell 153, 376-388 (2013).

47. K. Mohrs, A. E. Wakil, N. Killeen, R. M. Locksley, M. Mohrs, A two-step process for cytokine production revealed by IL-4 dual-reporter mice. Immunity 23, 419-429 (2005).

48. Y. Y. Wan, R. A. Flavell, Identifying Foxp3-expressing suppressor T cells with a bicistronic reporter. Proc. Natl. Acad. Sci. U. S. A. 102, 5126-5131 (2005).

49. C. L. Maynard et al., Regulatory T cells expressing interleukin 10 develop from Foxp3+ and Foxp3- precursor cells in the absence of interleukin 10. Nat. Immunol. 8, 931-941 (2007).

50. D. R. Herbert et al., Alternative macrophage activation is essential for survival during schistosomiasis and downmodulates T helper 1 responses and immunopathology. Immunity 20, 623-635 (2004).

51. A. Natarajan, B. Wagner, M. Sibilia, The EGF receptor is required for efficient liver regeneration. Proc. Natl. Acad. Sci. U. S. A. 104, 17081-17086 (2007).

52. V. Bhardwaj et al., snakePipes: facilitating flexible, scalable and integrative epigenomic analysis. Bioinformatics 35, 4757-4759 (2019).

53. F. Ramirez et al., deepTools2: a next generation web server for deep-sequencing data analysis. Nucleic Acids Res. 44, W160-165 (2016).

54. A. Dobin et al., STAR: ultrafast universal RNA-seq aligner. Bioinformatics 29, 15-21 (2013).

55. Y. Liao, G. K. Smyth, W. Shi, featureCounts: an efficient general purpose program for assigning sequence reads to genomic features. Bioinformatics 30, 923-930 (2014).

56. M. I. Love, W. Huber, S. Anders, Moderated estimation of fold change and dispersion for RNA-seq data with DESeq2. Genome Biol 15, 550 (2014).

57. T. Stuart et al., Comprehensive Integration of Single-Cell Data. Cell 177, 1888-1902 e1821 (2019).

58. T. Hashimshony et al., CEL-Seq2: sensitive highly-multiplexed single-cell RNA-Seq. Genome Biol. 17, 77 (2016).

59. J. S. Herman, Sagar, D. Grun, FateID infers cell fate bias in multipotent progenitors from single-cell RNA-seq data. Nat Methods 15, 379-386 (2018).

60. H. Li, R. Durbin, Fast and accurate long-read alignment with Burrows-Wheeler transform. Bioinformatics 26, 589-595 (2010).

61. D. Grun, L. Kester, A. van Oudenaarden, Validation of noise models for single-cell transcriptomics. Nat Methods 11, 637-640 (2014).

62. D. Grun et al., De Novo Prediction of Stem Cell Identity using Single-Cell Transcriptome Data. Cell Stem Cell 19, 266-277 (2016).

63. L. Ferrer-Font et al., High-dimensional analysis of intestinal immune cells during helminth infection. Elife 9, (2020). 